\title{
A Escravidão entre dois Liberalismos
}

\author{
Alfredo Bosi
}

"It was freedom to destroy freedom."

W.E.B. Du Bois

\begin{abstract}
"Senhores, se isso fosse crime, seria um crime geral no Brasil; mas eu sustento que, quando em uma naçáo todos os partidos politicos ocupam o poder, quando todos os seus homens políticos tến sido chamados a exercê-lo, e todos eles são concordes em uma conduta, $\hat{\epsilon}$ preciso que essa conduta seja apoiada em razóes muito fortes; impossfivel que ela seja um crime, e haveria temeridade em chamá-la um erro."
\end{abstract}

Eusébio de Queirós - Fala à Câmara em 1852.

Uma das conquistas teoricas do marxismo foi ter descoberto que $\epsilon$ nas práticas sociais e culturais, fundamente enraizadas no tempo e no espaço, que se formam as ideologias e as expressōes simb6licas em geral.

O núcleo temático de A Ideologia Alemä, que Marx e Engels escreveram em 1846, expōe a relação íntima que as representaçōes de uma sociedade mantêm com a sua realidade efetiva. As práticas, tomando-se a palavra no seu sentido mais lato, são o fermento das idéias na medida em que estas visam a racionalizar aspiraçōes difusas nos seus produtores $e$ veiculadores. A ideologia compōe retoricamente (isto $\epsilon$, em registros de persuasāo) certas motivaçōes particulares e as dá como necessidades gerais. Nos seus discursos, $o$ interesse e a vontade exprimem-se, ou traem-se, sob a forma de algum princípio abstrato ou alguma razão de força maior.

A crítica histórica do século $\mathrm{XX}$ herdou esse olhar de suspeita.

Dizia Andrade Figueira, deputado escravista, ao combater na Câmara a proposta da Lei do Ventre Livre:

"Serei hoje a voz dos interesses gerais, agricolas e comerciais, diante do movimento que a propaganda abolicionista pretende imprimir à emancipação da escravatura no Brasil. Trata-se da conservação das forças vivas que existem no país e constituem exclusivamente a sua riqueza. É questão de damno vitando" 1 .

Para entender a articulação de ideologia liberal com pratica escravista é preciso refletir sobre os modos de pensar dominantes da classe política brasileira que se imp6s nos anos da Independência e trabalhou pela consolidação do novo Imperio entre 1831 e 1860 aproximadamente.

$O$ que atuou eficazmente em todo esse período de construção do Brasil como Estado autônomo foi um ideário de fundo conservador; no caso, um complexo de normas jurídico-políticas capazes de garantir a propriedade fundiária e escrava até o seu limite possível.

Não $€$ finalidade destas linhas retomar o quadro histórico do sistema agroexportador que caracterizou a sociedade brasileira do século XIX. Obras notáveis já o fizeram com riqueza de dados e abonaçōes textuais. Supōe-se aqui a sua leitura, não importando, antes servindo de

1 FIGUEIRA, A. Anais do Parlamento. Rio, Tip. Villeneuve, 1871. Apêndice, p. 26. 
estímulo, a diversidade das posições teóricas que as enformam. Casa Grande \& Senzala e Sobrados e Mucambos, de Gilberto Freyre; Formação do Brasil Contemporâneo, de Caio Prado Jr.; História do Café no Brasil, de Affonso de Taunay; Capitalismo e Escravidão, de Eric Williams; Formação Econômica do Brasil, de Celso Furtado; Grandeza e Decadência do Café no Vale do Paraiba, de Stanley Stein; Capitalismo e Escravidão no Brasil Meridional, de Fernando Henrique Cardoso; As Metamorfoses do Escravo, de Octavio Ianni; $D a$ Senzala à Colônia, de Emília Viotti da Costa; Homens Livres na Ordem Escravocrata, de Maria Sylvia Carvalho Franco; A Formação do Povo no Complexo Cafeeiro, de Paula Beiguelman; Os Últimos Anos da Escravatura no Brasil, de Robert Conrad; e $O$ Escravismo Colonial, de Jacob Gorender - nos dão a análise do processo pelo qual os senhores de engenho e os fazendeiros de café regularam a vida econômica da nova nação e compuseram, desde a ruptura com o pacto colonial, a sua hegemonia em estreita conexão com o comércio internacional e o tráfico negreiro.

Quanto à obra política dessa classe, encontrou intérpretes de pulso em Tavares Bastos ( $A$ Província, Cartas do Solitário), Joaquim Nabuco (Um Estadista do Império), José Maria dos Santos (A Política Geral do Brasil), Victor Nunes Leal (Coronelismo, Enxada e Voto), Raymundo Faoro (Os Donos do Poder), José Honório Rodrigues (Conciliação e Reforma no Brasil) e Sérgio Buarque de Holanda (Do Império à República).

O objetivo deste ensaio é desenhar o perfil ideológico que correspondeu, efetivamente, ao regime de cativeiro a partir do momento em que o Brasil passou a integrar o mercado livre.

\section{Um Falso Impasse: ou escravismo ou liberalismo}

O par, formalmente dissonante, escravismo-liberalismo, foi, no caso brasileiro pelo menos, apenas um paradoxo verbal. O seu consórcio só se poria como contradição real se se atribuísse ao segundo termo,

liberalismo, um conteúdo pleno e concreto, equivalente à ideologia burguesa do trabalho livre que se afirmou ao longo da revolução industrial européia.

Ora, esse liberalismo ativo e desenvolto simplesmente não existiu, enquanto ideologia dominante, no período que se segue à Independência e vai até os anos centrais do Segundo Reinado.

A antinomia tantas vezes acusada, e o travo de nonsense que dela poderia nascer (mas como é possível um liberalismo escravocrata?), merecem um tratamento rigoroso que os desfaça.

Para entender o caráter próprio da ideologia vitoriosa nos centros de decisão do Brasil pós-colonial, convém examinar a sua evolução interna que acompanha o ascenso dos grupos escravistas. Formado ao longo das crises da Regência, o núcleo conservador definiu-se, pela voz dos seus líderes, Bernardo Pereira de Vasconcelos, Araújo Lima e Honório Hermeto, como o "Partido da Ordem", no ano crítico de 1837 e logo após a renúncia de Feijó. A sua história é a de uma aliança estratégica, flexível mas tenaz, entre as oligarquias mais antigas do açúcar nordestino e as mais novas do café no Vale do Paraíba, as firmas

exportadoras, os traficantes negreiros, os parlamentares que lhes davam cobertura, e o braço militar chamado sucessivas vezes, nos anos de $1830 \mathrm{e}$ 40, para debelar surtos de facções que espocavam nas províncias. Ao radicalismo impotente desses grupos locais opôs-se, desde o começo, o chamado liberalismo moderado, que exerceu, de fato, o poder tanto na fase regencial quanto nos anos iniciais do Segundo Império. As divisōes internas não tocaram sua unidade profunda na hora da ação.

O tráfico, mais ativo do que nunca, trouxe aos engenhos e às fazendas cerca de $700 \mathrm{mil}$ africanos entre $\mathbf{1 8 3 0}$ 
e 1850. As autoridades, apesar de eventuais declaraçōes em contrário, faziam vista grossa à pirataria que facultava o transporte de carne humana, formalmente ilegal desde o acordo com a Inglaterra em 1826 e a lei regencial de 7 de novembro de 1831. A última qualificava como livres os africanos aqui aportados dessa data em diante ... Lembro a "Fala do Negreiro", personagem da comedia de Martins Pena, Os Dous ou o Inglês Maquinista:

- Há por aí além uma costa tão larga e algumas autoridades tão condescendentes!...

Estávamos em 1842.

A observação do comediógrafo rima perfeitamente com os dados levantados por Robert Conrad para aqueles mesmos anos:

"Os juízes dos distritos em que os escravos eram desembarcados passavam a receber comissōes regulares, referidas como sendo fixadas em $10,8 \%$ do valor de cada africano desembarcado. Os escravos eram trocados diretamente por sacas de café nas praias, reduzindo assim a fórmula econômica - 'o café é o negro' - a uma realidade",2

Conrad ilustra com numerosos fatos a conivência dos governos regencial e imperial a partir de 1837: "No regime de Vasconcelos o tráfico escravista se desenvolve com uma nova vitalidade que prosseguiu por aproximadamente 14 anos, sob regimes conservadores e liberais, apoiado e sustentado pelas próprias autoridades cuja tarefa era fazer cessar o tráfico"3.

Para conhecer o ponto de vista do outro lado (o governo inglês), o melhor testemunho é o de Gladstone, primeiro-ministro, que, falando à Câmara dos Comuns em 1850, desabafava: "Temos um tratado com o Brasil, tratado que esse país dia a dia quebra, há vinte anos. Forcejamos por assegurar a liberdade dos africanos livres; trabalhamos ate conseguir que os brasileiros declarassem criminosa a importação de escravos. Esse acordo é incessantemente transgiedido"4.

O tratado anglo-brasileiro de 1826 já arrancara, de resto, protestos nacionalistas desde a sessão da Câmara de 1827, em que se propôs nada menos que a sua impugnação. $O$ representante de Goiás, brigadeiro Cunha Matos, aplaudido por vários colegas, deplorou que os brasileiros tivessem sido "forçados, obrigados, submetidos e compelidos pelo governo britânico a assinar uma convenção onerosa e degradarite sobre assuntos internos, domésticos e puramente nacionais, da competência exclusiva do livre e soberano legislativo e do augusto chefe da nação brasileira"5. Clemente Pereira, cujas antigas bandeiras maçônicas e ilustradas eram notorias, e que fora um dos pilares da Independência, também se pronunciou contra a ingerência britânica no controle dos navios negreiros; medida que verberou como "o ataque mais direto que se poderia fazer à Constituição, à dignidade nacional, à honra e aos direitos individuais dos cidadãos brasileiros" 6 . Para toda a retórica desse período vale a frase de José de Alencar: "ser liberal significava ser brasileiro" (Cartas a Erasmo, VI).

A argumentação conseguiu, de fato, ser nacionalista e bravamente fiel aos
$O$ objetivo deste ensaio é desenhar o perfil ideológico que correspondeu, efetivamente, ao regime de cativeiro a partir do momento em que o Brasil passou a integrar o mercado livre.

2 CONRAD, R. Os Tumbeiros. São Paulo, Brasiliense, 1985. p. 103-4.

3 Ibid., p.118. Veja-se também a análise de Stanley Stein: "O aumento das importações de escravos na década de 1840 beneficiou tanto os fazendeiros como os cofres públicos; em 1848 perto de $60 \%$ das contribuiçōes do município de Vassouras, Província do Rio de Janeiro, procediam de impostos sobre a venda de escravos" (Grandeza e Decadência do Café no Vale do Paraíba. São Paulo, Brasiliense, 1961. p. 161).

4 DUQUE-ESTRADA, O. A Abolição (esboço histórico). Rio, Leite Ribeiro \& Maurílio, 1918. p. 28.

5 BETHELL, L. A abolição do tráfico escravo no Brasil. São Paulo, EDUSP, 1976. p. $73-4$.

6 Ibid., p. 74. 
principios do livre-comercio. Em 1835, Bernardo Pereira de

Vasconcelos, ainda moderado, proporia emenda revogando a lei antiescravista de 1831: a sua atitude recebeu apoio maciço dos deputados à Assembleia Provincial de Minas Gerais.

A defesa patriótica do tráfico não era, aliás, apanágio de parlamentares mineiros. Na Câmara de Paris, onde é razoável supor que o liberalismo estivesse em casa sob a batuta de Luís Filipe, a maioria dos deputados vetou o acordo que Guizot fizera, em 1841, com a Inglaterra permitindo que fiscais da Marinha britânica inspecionassem navios franceses suspeitos de carregar negros?.

Enrichessez-vous! Entre os hesitantes, ainda àquela altura, estava Alexis de Tocqueville. A defesa da integridade nacional se sobrepunha aos escrúpulos então ditos filantrópicos e, afinal, resguardava os tumbeiros.

O discurso dominante de 1836 a 1850 foi, entre n6s, uma variante pragmática de certas posiçбes ja assumidas pelos chamados patriotas ou liberais histbricos, que herdaram os frutos do Sete de Setembro. E por que históricos? Porque foram, sem dúvida, as lutas da burguesia agroexportadora que tinham cortado os privilégios da Metrópole graças à abertura dos portos em 1808; esses mesmos patriotas tinham garantido, para si e para a sua classe, as liberdades de produzir, mercar e representar-se na cena política. Dar, o carcter funcional e topico do seu liberalismo. Quanto aos conservadores, assim autobatizados de 1836 em diante, apenas secundaram os moderados, a cujo grêmio atê então pertenciam, sucedendo-os nas práticas do poder e baixando o tom da sua retórica.

Mantendo sob controle terras, cafe e escravos, bastava-lhes o registro seco, prosaico, às vezes duro, da linguagem administrativa. É o estilo da eficiência: o estilo "saquarema" de Eusébio, Itaboraf, Uruguai, Paraná.
Comércio livre, primeira e principal bandeira dos colonos patriotas, não significava, necessariamente, e năo foi, efetivamente, sinônimo de trabalho livre. O liberalismo econômico não produz sponte sua, a liberdade social e política.

O comércio franqueado às naçōes amigas, que o término do exclusivo acarretou, nāo surtiu mudanças na composiçāo da força de trabalho: esta continuava escrava (não por inercia, mas pela dinâmica mesma da economia agroexportadora), ao passo que a nova prática mercantil pós-colonial se honrava com o nome de liberal. Daí resulta a conjunção peculiar ao sistema econômico-polf́tico brasileiro, e não s6 brasileiro, durante a primeira metade do século XIX: liberalismo mais escravismo. A boa consciência dos promotores do nosso laissez-faire se bastava com as franquezas do mercado.

Nesse bloco histórico năo $€$ de estranhar absolutamente que a supressảo do tráfico demorasse, como demorou, 25 anos para efetuar-se ao arrepio de tratados que expressamente o proibiam. Quanto à abolição total, s6 viria a ser decretada em 1888, isto $\epsilon$, só quando a imigração do trabalhador europeu ja se fizera um processo vigoroso em São Paulo e nas províncias do Sul.

Volto à compreensão contextual, nāo-abstrata, do termo liberalismo. Enquanto opção cultural, de corte europeu, afim à luta burguesa na Inglaterra e na França, o liberalismo político se abriria, lentamente aliás, para um projeto de cidadania ampliada. Essa, porém, não era a situaçāo brasileira onde a Independência não chegou a ser um conflito interno de classes. $O$ confronto aqui se deu, fundamentalmente, entre os interesses dos colonos e os projetos recolonizadores de Portugal, na verdade já reduzido a quase-impotência depois da abertura

7 COHEN, W. Français et Africains. Les Noirs dans le regard des Blancs (1530-1880).

Paris, Gallimard, 1981. p. 42-9, 271-78. 
dos portos em 1808. Os nossos patriotas ilustrados cumpriram a missão'tle cortar o fio umbilical também na esfera jurfdico-política.

Sob a hegemonia dos moderados e, depois, dos regressistas, o liberalismo pós-colonial deitou raizes nas práticas reprodutoras e autodefensivas daqueles mesmos colonos, enfim emancipados. $O$ seu movimento conservou as franquias obtidas na fase inicial, antilusitana, do processo, mas jamais pretendeu estendê-las ou reparti-las generosamente com os grupos subalternos. $O$ nosso liberalismo esteve assim apenas à altura do nosso contexto.

"Liberalismo" - diz Raymundo Faoro - "nāo significava democracia, termos que depois se iriam dissociar, em linhas claras e, em certas correntes, hostis" 8 .

A pergunta de fundo $\epsilon$ então: $o$ que pôde, estruturalmente, denotar o nome liberal, quando usado pela classe proprietária no período de formação do novo Estado?

Uma análise semântico-histórica aponta para quatro significados do termo, os quais vêm isolados ou variamente combinados:

1) Liberal, para a nossa classe dominante até os meados do século XIX, pôde significar conservador das liberdades, conquistadas em 1808 , de produzir, vender $e$ comprar.

2) Liberal p6́de, então, significar conservador da liberdade,

- alcançada em 1822, de representar-se politicamente; ou, em outros termos, ter o direito de eleger e de ser eleito na categoria de cidadâo qualificado.

3) Liberal pôde, entäo, significar conservador da liberdade (recebida como instituto colonial e relançada pela expansão agrícola) de submeter o trabalhador escravo mediante coação juridica.
4) Liberal pôde, enfim, significar capaz de adquirir novas terras em regime de livre concorrência, alterando assim o estatuto fundiário da Colónia no espírito capitalista da Lei de Terras de 1850.

A classe fundadora do Imperio do Brasil consolidava, portanto, as suas prerrogativas económicas e políticas. Econômicas: comércio, produção escravista, compra de terras. Políticas: eleições indiretas e censitárias. Umas e outras davam um conteúdo concreto ao seu liberalismo. Que se tornou, por extensão e diferenciação grupal, o fundo mesmo do ideário corrente nos anos 40 e 50 .

A historiografia da Regência já contou, por miúdo, a passagem do partido moderado, no qual se encontravam todos, Evaristo e Feijo, Vasconcelos e Honório Hermeto, para o Regresso (termo adotado a partir de 1836), quando os últimos alijaram $e$ substituíram os primeiros, a pretexto de impor a ordem interna ameaçada pelas rebeliōes provinciais. É significado pontual da arquicitada profissão de fé de Vasconcelos, mentor da reação que vai marcar o início do Segundo Reinado:

"Fui liberal, então a liberdade era nova no país, estava nas aspiraçōes de todos, mas nāo nas leis, nas idéias práticas; o poder era tudo; fui liberal. Hoje, porém, é diverso o aspecto da sociedade: os princípios democráticos tudo ganharam e muito comprometeram; a sociedade, que então corria o risco pelo poder, corre agora o risco pela desorganização e pela anarquia. Como então quis, quero hoje servi-la, quero salva-la, e por isso sou regressista. Nâo sou trânsfuga, não abandono a causa que defendi no dia de seus perigos, da sua fraqueza, deixo-a no dia em que tăo seguro é o seu triunfo que até o excesso a compromete",

8 FAORO, R. Existe um pensamento político brasileiro? Estudos Avançados. São Paulo, (1): 44, out./dez. 1987.

9 Apud Joaquim Nabuco, Um Estadista do Império. 2ª ed. Rio, Ed. Nova Aguilar, 1975. p. 69. 
Em outras palavras, $o$ discurso quer dizer: a política de centralização é o antídoto necessário a uma divisão do País, que, por seu turno (e aí vem a razão calada), seria fatal ao novo centro econômico valparaibano.

O percurso de Vasconcelos e o êxito político do Regresso fazem pensar que a moderação dos liberais de 1831 acabaria, cedo ou tarde, assumindo a sua verdadeira face, conservadora. Os traficantes foram poupados; e os projetos iluministas, raros e esparsos, de abolição gradual foram reduzidos ao silêncio. Deu-se ao Exército o papel de zelar pela unidade nacional contra as tendências centrífugas dos clās provinciais. Vencidos os últimos Farrapos, estava salva a sociedade: no caso, o Estado aglutinador de latifundiários, seus representantes, tumbeiros e burocracia. A retórica liberal trabalha seus discursos em torno de uma figura redutora por excelência, a sinédoque, pela qual o todo é nomeado em lugar da parte, implícita.

Hermes Lima, no prefácio que escreveu para $A$ Queda do Império de Rui Barbosa, entende o Regresso como um mecanismo político de estratégia dos grupos que se destacaram do bloco liberal-moderado no exato momento (1835-37) em que a expansão do café no Vale do Paraỉba demandava maior ingresso de africanos. A propriedade escrava e, no seu bojo, o tráfico, passavam a ser, efetivamente, $o$ eixo de uma economia que se montara na esteira da liberação dos portos e das franquias comerciais. "It was freedom to destroy freedom", na frase lapidar de Du Bois.

Nessa altura, os cafeicultores almejavam um Estado forte, uma administração coesa e prestante ou, nos seus repetidos termos, precisavam manter, a todo custo, a unidade nacional. Foi a bandeira do Regresso. $O$ padre Feijo, renunciando ao cargo de Regente em meio a dificuldades extremas, fizera perigar o cumprimento desse desígnio, na medida em que supunha ser inevitável a tendência separatista de algumas províncias mais turbulentas como Pernambuco e o Rio Grande do Sul. Somando-se a essa atitude de desistência de sua luta, outrora tão ferrenha contra as facções locais, teria havido no padre paulista um maior empenho de honrar os acordos antitráfico feitos com a Inglaterra e sabotados por uma legião de




coniventes. Em contrapartida, a ala saquarema, que toma em 1837 o lugar de Feijo, reacende manu militari o ideal de um Império unido, ao mesmo tempo que vai transigindo largamente com o comércio negreiro, o que insufla alento às bases do novo complexo agroexportador.

Tudo se apresenta imbricado: o centralismo se diz nacional e vale-se do Exército, que toma vulto no período; o tráfico é utilíssimo à expansão do café; enfim, o Partido da Ordem abraça todas essas bandeiras que, plantadas no centro do poder, a Corte fluminense, irăo manter-se firmes ate, pelo menos, os fins dos anos 50. O Partido Liberal, em grande parte desertado, ora alterna com o Conservador, ora com este se combina, mas, em ambos os casos, os discursos oficiais se alinham com os compromissos oligárquicos, sua moeda corrente. Joaquim Nabuco acertou em cheio ao historiar a situação: a reação conservadora "pretendia representar a verdadeira tradição liberal do país"10. E Octávio Tarqüínio de Sousa também advertiu os liames entre os moderados e os regressistas:

"Bem consideradas, porém, as coisas, nenhuma divergência substancial os dividia: o 'regresso' de Vasconcelos não contradizia a 'moderação' de Evaristo: era apenas uma evolução, uma transformação; o 'regresso' consolidava por assim dizer a obra da 'moderação" "11. O tom apologético não infirma a justeza da análise...

Nada haveria, a rigor, de excêntrico, deslocado ou postiço na linguagem daqueles políticos brasileiros que, usando o termo liberalismo em um sentido datado, pro domo sua, legitimaram o cativeiro por um tempo tâo longo e só o restringiram sob pressâo internacional. Uma proposta moderna e democrática sustentada pelas oligarquias rurais é que teria sido, nos meados do século XIX, uma idéia extemporânea. Mas esse projeto não se concebeu nem aqui, nem em Cuba, nem nas Antilhas inglesas e francesas que viviam o mesmo regime de plantation, nem no reino do algodão do Velho Sul americano. Em todas essas regiōes, políticos defensores do liberalismo económico ortodoxo velaram pela manutenção do trabalho escravo.

Nem houve propriamente ficçōes jurídicas, à européia, ocultando o latifúndio, o tráfico, a escravidão. Houve, sim, um uso bastante eficaz das instituiçōes parlamentares pelos senhores de engenho e das fazendas. As Câmaras serviam de instrumento à classe dominante que, sem os canais jurídicos estabelecidos, não controlariam a administração de um tão vasto país. "Máquina admirável", assim chamou o nosso regime parlamentar e monárquico um paladino da reação conservadora ${ }^{12}$.

No fim do Primeiro Império a oposição a D. Pedro I fora comandada por homens fiéis ao parlamentarismo inglês como Bernardo Pereira de Vasconcelos que, ao mesmo tempo (1829), escandalizava o reverendo Robert Walsh por sua atitude escravista: "Entre as fraquezas de Vasconcelos está advogar a causa do trafico de escravos; e o tratado com a Inglaterra para sua tbolição total em breve, e a nossa disposiçāo em fazê-lo cumprir se contam entre as suas reservas a nosso respeito"13. Um ressentimento amargo contra os ingleses fiscais do oceano, e que lembra a anglofobia dos confederados sulinos, não era peculiar a Vasconcelos apenas.
Nada haveria, a rigor, de excêntrico, deslocado ou postiço na linguagem daqueles políticos brasileiros que, usando o termo liberalismo em um sentido datado, pro domo sua, legitimaram - cativeiro por um tempo tão longo e só o restringiram sob pressão internacional.

10 Id. ibid.

11 TARQÜINIO de SOUSA, O. Evaristo da Veiga. Belo Horizonte/São Paulo, Itatiaia EDUSP, 1988. p. 153.

12 SILVA, P. O Brasil no Reinado do Sr. D. Pedro II.' In:-. Escritos políticos e discursos parlamentares. Rio, Garnier, 1862. p. 28. (Escrito na língua francesa e publicado na Revue des deux mondes, de 15 de abril de 1858).

13 TARQÜÍNIO de SOUSA, O. Bernardo Pereira de Vasconcelos. São Paulo, Itatiaia EDUSP, 1988. p. 77. 
Mas nada turvava a admiração pelos discursos da Câmara dos Comuns ... Os gabinetes e os Conselhos de Estado que congelaram, por largos anos, as idéias de emancipação (mesmo quando bafejadas pelo Imperador, como ocorreu nas Falas do Trono de 67 e 68) reuniam homens para os quais os chamados princípios liberais só adquiriam um sentido forte, e até concitante e polêmico, quando aplicados ao já clássico debate entre constitucionais e absolutistas. A discussão não era acadêmica nem bizantina. A luta, que fôra crucial na Europa pós-napoleônica até a Revolução de 1830 , encontrou aqui variantes nas arremetidas dos patriotas contra o jugo da metrópole e, pouco depois, contra os ímpetos voluntariosos de Pedro I. O liberalismo à inglesa se fazia necessário para que a classe economicamente dominante assumisse o seu papel de grupo dirigente. Esse o alcance e limite do nosso liberalismo oligárquico.

Analisando a conduta autodefensiva dos liberais, comentava Saint-Hilaire no ano em que se fazia a Independência:

"Mas são estes homens que, no Brasil, foram os cabeças da Revolução; não cuidavam senão em diminuir o poder do Rei, aumentando o próprio. Não pensavam, de modo algum, nas classes inferiores" 14 .

$O$ arguto observador poderia ter dito, utilizando o jargão da época: "Esses homens eram liberais constitucionais".

Parlamentares ardidos em face da Coroa, antidemocratas confessos perante a vasta população escrava ou pobre. Nem rei, nem plebe: nós.

O contrato social fechado e excludente, propício aos homens que tinham concorrido para desfazer o pacto colonial, verteu-se em um documento solene. Foi a Constituição de 1824. A Carta, apesar de outorgada por um gesto autoritário de Pedro I, satisfez à maioria dos novos pactários que detinham, de fato, o poder decisório da recente nação. Era uma aliança entre os direitos dos beati possidentes e os privilégios do monarca. O liberalismo restrito do seu texto não destoava das cautelas da Carta restauradora francesa que, em 1814 , acolhera entre os seus mecanismos de governo a figura do Poder Moderador teorizada por Benjamin Constant. As liberdades fruídas pelos citoyens (cidadãos-proprietários) exorcizavam o fantasma de uma igualdade tida por abstrata e anárquica, e que, se realizada, somaria imprudentemente possuidores e não-possuidores. E por que esse liberalismo a meias, corrente na França cartista, não se ajustaria como uma luva à mais que exígua classe votante do Brasil Império? Por acaso as propostas levadas à Assembléia Constituinte em 1823 tinham ido além da proteção à agricultura, ao livre-câmbio, ao comércio franco? Deixara-se intacta a instituição do trabalho forçado. A Representação de José Bonifácio não chegou a ser matéria de debate.

Promulgada a Lei Maior, logo engendrou-se o mito da sua intocabilidade, tônica dos discursos da oligarquia até o fim do regime. Os deputados conservadores preferiam, ainda em 1864, chamar-se, pura e simplesmente, "constitucionais". Assim fazendo, abriram uma brecha para os liberais se apoderarem de um rótulo que ficara vago e os tentava: na mesma ocasião criou-se um grupo "liberal-conservador"...

A Carta virou um perdão sacralizado pela aura dos tempos heróicos da Independência. Por trás do seu pesado biombo auriverde, onde os mesmos fios de seda bordavam ramos de café $e$ de fumo e o escudo dinástico dos Braganças, aninhavam-se $o$ voto censitário, a eleição indireta e o direito inviolável à propriedade escravista.

14 SAINT-HILAIRE, A. Segunda viagem do Rio de Janeiro a Minas Gerais e a São Paulo. Trad. revista e prefácio de Vivaldi Moreira. São Paulo, Itatiaia - EDUSP, 1974. p. 94. 
A tática centralizante da última Regência, que a precoce maioridade de Pedro II viria consumar, foi mais uma garantia para a burguesia fundiária; o fato de ter sido apressada por alguns militantes da facçāo liberal não impediu que seus frutos fossem depressa colhidos e longamente saboreados pelos saquaremas. A partir de 1843 a Câmara $\epsilon$ invadida por uma "cerrada falange reacionária"15.

Rebatendo para as condições européias: o regresso, difuso ou instituído, foi também o protagonista ideológico entre o Congresso de Viena e a Revoluçāo de 48. A síntese cortante de Eric Hobsbawm diz bem a situação: "O liberalismo e a

democracia pareciam mais adversários que aliados; o tríplice slogan da Revolução Francesa - liberdade, igualdade e fraternidade - expressava melhor uma contradição do que uma combinação"16.

Lá, uma política utilitária amarrou-se estruturalmente à espoliação sem nome do novo proletariado. Aqui, o nosso ideário constitucional se nutriu do suor e do sangue cativo. Cá e lá os poderes cunharam a moeda fácil do nome liberal.

De qualquer modo, a especificidade reponta: o sistema de plantagem retardou ou fez involuir ideais ou surtos de caráter progressista. No começo do Segundo Reinado, a geração constitucional, abrigada à sombra do café valparaibano, resistiu ao governo inglês em tudo o que dissesse respeito ao trafico.

Conhece-se a posição drástica de Vasconcelos que não mudou até à sua morte em 1850. Em 1843, o lobby dos escravistas espalhados pelas várias províncias brasileiras parecia a Lord Brougham tão eficiente quanto cínico:

"Em primeiro lugar, temos a declaração expressa de um homem de bem do Senado do Brasil, de que a lei que aboliu o tráfico de escravos é notoriamente letra morta, tendo caído em desuso. Em segundo lugar, temos uma petição ou memorial da Assembléia Provincial da Bahia ao Senado urgindo pela revogação da lei; não que ela os incomode muito, mas porque a cláusula de que 'os escravos importados depois de 1831 são livres' embaraça a transação da venda e torna inconveniente possuir negros há pouco introduzidos no país. Eu encontro outra Assembléia Provincial, a de Minas Gerais, pedindo a mesma coisa com iguais fundamentos. Depois de insistir nos perigos para o país da falta de negros, o memorial acrescenta: - 'Acima de tudo, o pior de todos esses males é a imoralidade que resulta de habituarem-se os nossos cidadãos a violar as leis debaixo das vistas das próprias autoridades!' Eu realmente acredito que a história toda da desfaçatez humana não apresenta uma passagem que possa rivalizar com essa nenhum outro exemplo de ousadia igual. Temos neste caso uma Legislatura Provincial, que se apresenta por parte dos piratas e dos seus cúmplices, os agricultores, que aproveitam com a pirataria, comprando-lhes os frutos, e em nome desses grandes criminosos insta pela revogação da lei que o povo confessa estar violando todos os dias, e da qual eles declaram que não hão de fazer caso enquanto continuar sem ser revogada; pedindo a revogação dessa lei com o fundamento de que, enquanto ela existir, resolvidos como estão a violá-la, eles se vêem na dura necessidade de cometer essa imoralidade adicional debaixo das vistas dos juízes que prestaram o juramento de executar as leis"17.

O trabalho escravo era um fator estrutural da economia brasileira, tanto que o seu controle interno se fazia cada vez mais rígido. Em 1835 , ainda antes de os regressistas chegarem ao poder, o parlamento liberal-moderado votou uma lei que punia de morte qualquer ato de

15 NABUCO, J. Um Estadista ... op. cit., p. 77.

16 HOBSBAWM, E. A era das revoluçōes. Europa. 1780-1848. $5^{\mathrm{a}}$ ed. Rio, Paz e Terra, 1986. p. 262.

17 NABUCO, J. O Abolicionismo. 4ª ed. Petrópolis, Vozes, 1977. p. 117-8. 
rebeldia ou de ofensa aos senhores praticado por escravos.

Esse, o quadro nacional. Mereceria um estudo comparativo a resistência à abolição nas colônias da Inglaterra, da França e da Holanda, países onde o pensamento liberal burguês já tomara a dianteira internacional. $O$ governo britânico só promoveu a alforria geral nos seus domínios em 1833, com indenizaçāo plena aos proprietários, o que implicava reconhecimento aos direitos destes. $O$ parlamento holandês decretou a abolição em Suriname a partir de 10 de julho de 1863, pagando aos fazendeiros e "ficando os libertos sob proteção especial do Estado"18.Quanto aos escravos da Guiana e das Antilhas Francesas, tiveram de esperar pelo decreto do Conselho Provis6rio de 27 de abril de 1848 para receberem a libertação coletiva que também importou em ressarcimento aos senhores. De pouco valera o belo gesto dos Convencionais que tinham aplaudido de pé a aboliçáo no memorável Dezesseis do Pluvioso do Ano II da Revolução, 4 de fevereiro de 1794. Em 1802 Napoleão legaliza de novo a instituição que ainda agüentaria meio século. Cá e lá...

\section{"Laissez-faire" e Escravidāo}

Há uma dinâmica interna no velho liberalismo econômico que, levando às últimas conseqüências a vontade de autonomia do cidadão-proprietário, se insurge contra qualquer tipo de restrição jurídica à sua esfera de iniciativa.

Celso Furtado viu com perspicácia que os nossos economistas liberais, a partir do visconde de Cairu, se mostraram mais feéis a Adam Smith do que os proprios ingleses e yankees...
A doutrina do laissez-faire data da segunda metade do século XVIII, com o advento da hegemonia burguesa, que assestou um golpe de morte nas corporaçōes de ofícios e nos privilegios estamentais. Mas há também um uso colonial-escravista dos princípios ortodoxos; uso que, em retrospectiva, nos pode parecer abusivo ou cínico, mas que serviu cabalmente à lógica dos traficantes e dos senhores rurais.

Um mercador da costa atlântica da África citava, em favor de seus direitos de livre cidadāo britânico (free-born), a Magna Carta, a qual the conferia o poder inalienável de comerciar o que bem entendesse, dispondo com igual franquia de todas as suas propriedades móveis, semoventes e imóveis ${ }^{19}$. Esse direito, alegado por um negreiro em 1772 , seria ainda a base de sustentação jurídica dos parlamentares que, no Brasil de 1884, obstaram aos trâmites da proposta do conselheiro Dantas que visava a alforriar os escravos maiores de 60 anos sem indenização aos senhores. O ministério caiu; e o Saraiva, que o sucedeu, teve que manter o princípio do pagamento obrigatório. Direito individual à propriedade de homens: valido em 1772, válido em 1884.

Celso Furtado viu com perspicácia que os nossos economistas liberais, a partir do visconde de Cairu, se mostraram mais fieis a Adam Smith do que os próprios ingleses e yankees; os últimos souberam, sob a influência de Hamilton, dosar livre-comércio e protecionismo industrial sempre que lhes conveio. Comparando as idéias de Alexander Hamilton com as de Cairu, diz Furtado: "Ambos são discípulos de Adam Smith, cujas idéias absorveram diretamente e na mesma época na Inglaterra. Sem embargo, enquanto Hamilton se transforma em paladino da industrialização (...) Cairu crê supersticiosamente na mão invisível e repete: deixai fazer, deixai passar, deixai vender" 20 .

A observação é válida sobretudo para o perfodo em que a hegemonia regressista casou laissez-faire e trabalho escravo. Vasconcelos, que ja

18 MALHEIRO,P. A escravidão no Brasil. 2 ed. Petrópolis, Vozes, 1976. v. II, p. 301.

19 A Treatise upon trade from Great-Britain to Africa; humbly recommended to the attention of Government by an African Merchant. London, printed for R. Baldwin, n. 47, Pater-Noster Row, 1772.

20 FURTADO, C. Formação econômica do Brasil. Rio, Fundo de Cultura, 1959. p. 123. 
vimos defender abertamente o tráfico (a ponto de propor a suspensão dos efeitos manumissores da lei de 1831!), era acérrimo inimigo de qualquer medida oficial que amparasse a incipiente manufatura brasileira em prejuízo da importação de produtos europeus. Porta-voz da mentalidade agrária, vitoriosa nas eleições de 1836, Vasconcelos recusava a própria idéia da presença estatal na economia, valendo-se para tanto dos argumentos clássicos:

"A nossa utilidade não está em produzir os gêneros e mercadorias, em que os estrangeiros se nos avantajam; pelo contrário devemos aplicar-nos às produções em que eles nos são inferiores. Nem é preciso que a lei indique a produçāo mais lucrativa: nada de direção do governo. $O$ interesse particular é muito ativo e inteligente; ele dirige os capitais para os empregos mais lucrativos: a suposição contrária assenta numa falsa opiniăo, de que só o governo entende bem o que é útil ao cidadão e ao Estado. O governo é sempre mais ignorante que a massa geral da nação, e nunca se ingeriu na direção da indústria que não a aniquilasse, ou pelo menos a acabrunhasse. (...) Favor e opressão significam o mesmo em matéria de indústria, o que $\varepsilon$ indispensável é guardar-se o mais religioso respeito à propriedade $\mathrm{e}$ liberdade do cidadão brasileiro. As artes, o comércio e a agricultura não pedem ao governo se não o que Dígenes pediu a Alexandre retira-te do meu sol - eles dizem em voz alta - não temos necessidade de favor: o-de que precisamos é liberdade e segurança" 21. Adam Smith e Say não teriam sido mais enfáticos.

Mutatis mutandis (ma non troppo), foi a linguagem da UDN e é a linguagem da UDR.

Mas qual era, a partir do tratado de 1826, o principal óbice à prática desse liberalismo ortodoxo tão cioso dos seus direitos? Era, precisamente, o controle do governo inglês exercido sobre o mercado negreiro internacional. Vasconcelos indignava-se com a pregação dos philanthropists, em plena atividade, e se desabafava nestas palavras recolhidas por Walsh: "Eles protestam contra a injustiça desse comércio, dando como exemplo a imoralidade de algumas naçōes que o aceitam; não ficou, porém, demonstrado que a escravidão chegue a desmoralizar a tal ponto qualquer nação. Uma comparação entre o Brasil e os países que não têm escravos irá tirar qualquer dúvida a esse respeito". Acrescenta o reverendo, chocado: "Em seguida sugeriu que o governo brasileiro deveria entrar em acordo com a Inglaterra sobre a prorrogação da lei" 22 . $O$ argumento de

Vasconcelos escorava-se no confronto entre as condiçōes de trabalho no Brasil e na Europa, e voltaria com insistência nos discursos liberal-regressistas, sendo retomado por José de Alencar nas tumultuosas sessōes que precederam à votação da Lei do Ventre Livre.

Esboça-se aqui a síndrome do liberalismo oligárquico brasileiro (e, no limite, neocolonial): entrosamento do País em uma rígida divisão internacional de produção; defesa da monocultura; recusa de toda interferência estatal que não se ache voltada para assegurar os lucros da classe exportadora. É claro que a proibição do comércio negreiro por parte do Estado (no caso, premido pela Inglaterra) restringiria a livre iniciativa do vendedor e do comprador da força de trabalho. O mesmo pensamento fez escola entre os escravistas do Old South dos quais saiu uma plêiade de economistas ortodoxos:

Thomas Cooper, autor de um manual smithiano bastante divulgado até os meados do século XIX (Lectures on

21 Citado, elogiosamente, por Sílvio Romero, na História da Literatura Brasileira. 5־ ed. Rio, J. Olympio, 1953. v. V, p. 1727-29. A referência ao pedido que Diógenes fez a Alexandre ("Retira-te do meu sol!'”) já estava nos escritos de Bentham contra o protecionismo à indústria nacional...

22 WALSH, R. Notícias do Brasil. São Paulo, Itatiaia - EDUSP, 1985. p. 109. 
the Elements of Political Economy, 1826); George Tucker, primeiro titular de Economia da Universidade de Virgínia; e, sobretudo, Jacob Newton Cardozo, um dos redatores influentes da Southern Review, todos contestavam a idéia de que o braço cativo fosse unprofitable. Para os sulistas, aqueles que teimavam em julgar a escravidão pouco rentável de certo atinham-se a uma concepção unilateral e abstrata da nova ciência, a qual crescia tão lentamente porque "os economistas europeus, ao tentarem construir sistemas de aplicação geral para todos os países, continuam, no fundo, a supor que as suas circunstâncias são naturais e universais. Nós sabemos que as riquezas das naçōes crescem a partir de fontes largamente diferentes. Por exemplo, a experiência revela que a escravidão no Sul tem produzido não só um alto grau de riqueza, como também uma partilha maior de felicidade para o escravo do que ocorre em muitos lugares onde a relação entre o empregador e o empregado é baseada em salários"23. A mensagem política que aflora no texto é simples: deixai as coisas como estāo, deixai-nos plantar nosso algodāo, alargar nossas fronteiras, comprar escravos do Norte, ganhar dinheiro com o tráfico etc.

Se o nosso regime escravocrata devia enfrentar a Inglaterra, o laissez-faire algodoeiro do Sul desafiava a Uniāo, de onde partiam as leis restritivas: "Por volta de 1854", diz John Hope

O desrespeito à lei antitráfico foi, nos Estados Unidos dos anos 50, tão frontal quanto o do Brasil nos anos 40. Cá e lá, a liberdade, sem mediaçōes, do Capital exigia a total sujeição do trabalho. tráfico. Na convenção do Montgomery de 1858 desencadeou-se um debate furioso sobre o problema. William $L$. Yancey, o comedor-de-fogo de Alabama, argumentava, com certa lógica, que "se $\epsilon$ um direito comprar escravos na Virgínia e levá-los a Nova Orléans, por que não $\epsilon$ direito compra-los em Cuba, no Brasil, ou na Africa, e levá-los para lá?’. Nova Orléans era, em 1858, o grande mercado negreiro americano.

Continua Franklin: "No ano seguinte, em Vicksburg, a convenção votou favoravelmente uma resolução recomendando que 'todas as leis, estaduais ou federais, que proíbem o comércio africano de escravos, deveriam ser revogadas'. Só os estados do Sul superior ("upper South"), que desfrutavam dos lucros obtidos pelo tráfico doméstico de escravos, se opuseram à reabertura do tráfico africano"24. O desrespeito à lei antitráfico foi, nos Estados Unidos dos anos 50, tão frontal quanto o do Brasil nos anos 40. Cá e lá, a liberdade, sem mediações, do Capital exigia a total sujeição do trabalho.

It was freedom to destroy freedom: dialética do liberalismo no seu momento de expansão a qualquer custo.

Um erudito historiador baiano escreveu, em 1844, um libelo contra a "deslealdade" da Inglaterra que, afetando ser amiga da nova naçăo brasileira, agia em nosso desfavor impedindo que a lavoura recebesse a preciosa mão-de-obra africana.

Trata-se do dr. A.J. Mello Moraes e do seu opúsculo: A Inglaterra e seos tractados. Memoria, na qual previamente se demonstra que a Inglaterra não tem sido leal até o presente no cumprimento dos seus tractados. Aos srs. deputados geraes da futura sessão legislativa de 1845.

23 DORFMAN, J. The economic mind in american civilization. New York, Augustes $M$. Kelley Publishers, 1966. Ver especialmente o capítulo "The Southern Tradition of laissez-faire". A involução do liberalismo do Sul para uma ideologia escravista total chamou a atenção de um ensaísta contemporâneo, lido por Marx e Engels, John Cairnes, que escreveu The Slave Power, em 1863.

24 FRANKLIN, J.H. From slavery to freedom. 5ª ed. New York, Alfredo Knopf, 1980. p. 81 . 
Volta aí a indefectível comparação:

"Um inglês trata cem vezes pior um criado branco e seu igual do que nós a um dos nossos escravos" 25 . A proposta de Mello Moraes é simples e drástica: o gabinete inglês "ou há de abandonar as suas colônias, por não haver gêneros coloniais para consumo, ou, se as quiser possuir, há de admitir a escravidão"26. Postulada a íntima relação entre produtos coloniais e cativeiro, nexo historicamente instituído e consolidado por três séculos, o bravo defensor da nossa lavoura exorta os deputados gerais, em campanha eleitoral, a cortar as amarras que ligavam o governo imperial ao britânico: "O Brasil para ser feliz não tem necessidade de tratados com nação alguma, pois basta somente proteger a agricultura, animar a indústria manufatureira, libertar o comércio, e franquear seus portos ao mundo inteiro. $\mathrm{O}$ Brasil não precisa dos favores da Inglaterra,"27. Poucas linhas atrás, Mello Moraes via com esperança o aumento das nossas exportações de café para os Estados Unidos. O espírito de 1808 , que rompera com o monopolio português, demandava agora seu pleno desdobramento. Nada de entraves.

$\mathrm{Na}$ esteira do processo de integração pós-colonial dos países

latino-americanos, o Brasil deveria realizar o princípio mais geral do sistema dando o maior raio possível de ação, legal ou ilegal, a quem de direito: ao senhor do cafe, ao senhor de engenho e aos seus agenciadores da força de trabalho, os traficantes.

Para a classe dominante o b́bice maior não vinha, então, do nosso Estado constitucional, que representava o latifúndio e dele se servia; o obstáculo era interposto pela nova matriz internacional, o novo exclusivo, a Inglaterra. Entende-se a reivindicação do mais desbridado laissez-faire; entende-se a hostilidade que despertava entre os proprietários o controle da sua nação por um Estado estrangeiro.

Mas como o denominador ideológico comum era o liberalismo econômico, que conhece na época a sua fase áurea, só restava à retórica escravista uma saída para o impasse: mostrar que as idéias mestras da doutrina clássica, porque justas, deveriam aplicar-se com justeza às circunstâncias, às peculiaridades nacionais.

A atenção e o respeito ostensivo ao particular, tão insistentes nos escritos conservadores de Burke, permeiam a ideologia romântico-nacional que vai de Varnhagen a Alencar, de Vasconcelos a Olinda, de Paraná a Itaboraí. Será o topos maior da argumentação de cunho protelatório: dar tempo ao tempo, já que o Brasil não é a Europa, e é preciso respeitar as diferenças.

Filtragem ideológica e contemporização, estas seriam as estratégias do nosso liberalismo intra-oligárquico em todo o período em que se construía o Estado nacional.

Para racionalizar os seus mecanismos de defesa, a ideologia do cafe valparaibano e a do algodão sulista, sua contemporânea, jamais puseram em dúvida o fundamento comum, que era $o$ direito absoluto à propriedade $\mathrm{e}$ ao livre-comércio internacional. $O$ princípio universal lhes servia tanto quanto ao liberal europeu. $O$ que se acrescentava era uma nova determinação, a do ajuste das idéias a interesses específicos. $O$ resultado dessa extensão foi, e tem sido, a notória guinada conservadora que as burguesias agrárias operam sempre que alguma sombra de ameaça se divisa no seu horizonte. Temos exemplos bastantes de um discurso ultraliberal de direita para não estranharmos essa química. Ainda neste 1988, um líder do chamado "centrão" junto à Assembléia Nacional Constituinte jactava-se de

25 MELLO MORAES, A.J. A Inglaterra e seos tractados... (opúsculo). Bahia, Tip. do Correio Mercantil de F. Vianna e Comp., 1844. p. 26.

26 Ibid., p. 33.

27 Id.'ibid., p. 41. 
ser reacionário em política, mas "anárquico" em economia: abaixo a interferência do Estado, tudo para a iniciativa privada!

No Brasil, por míngua de densidade cultural, a apologia do tráfico e do cativeiro não chegou a assumir formas tão elaboradas como no Velho Sul americano, onde a escravidão foi chamada, um sem número de vezes, "pedra angular (corner-stone) das liberdades civis".

Sigo a leitura convincente de Gunnar Myrdal em An American Dilemma:

"Politicamente os brancos eram todos iguais enquanto cidadãos livres. Livre competição e liberdade pessoal thes estavam asseguradas. Os estadistas do Sul e os seus escritores martelaram nessa tese, de que a escravidão, e só a escravidão, produzia a mais perfeita igualdade e a mais substancial liberdade para os cidadãos livres na

A presença ubíqua dos negros nivelava, sob um certo aspecto, todos os brancos, pois os chamava para um espaço comum, que os opunha, em bloco, à raça subordinada. $O$ trabalho escravo se constituía em condição primeira para a existência social do branco livre e proprietário. É o raciocínio de um escravista muito

Descontadas certas diferenças culturais, salta à vista do historiador a formação de uma ideologia liberal-escravista comum às três áreas em que a atividade agroexportadora se fez mais intensa a partir dos anos de 1830: o Brasil cafeeiro, o Sul algodoeiro e as Antilhas canavieiras, especialmente Cuba.

Jefferson Davis. Do ponto de vista da lógica da dominação, um raciocínio perfeito.

A combinação de laissez-faire, soberbo individualismo dos senhores, patriarcalismo grávido de arbítrio e favor, antiprotecionismo no que toca à indústria e elogio da vida rural foi-se construindo solidamente a partir dos anos de 1830, "sob a dupla influência da crescente lucratividade da escravidāo na economia de plantation sociedade" 28 .

e das arremetidas do movimento abolicionista do Norte"29.

Uma linguagem ao mesmo tempo liberal e escravista se tornou historicamente possível; ao mesmo tempo, refluía para as sombras do esquecimento a coerência radical-ilustrada da inteligência que amadurecera no último quartel do século XVIII.

Em Cuba, outra área típica de latifúndio exportador, a prosperidade da economia canavieira, a partir desses mesmos anos 30, resfriou os ideais libertários e enrijeceu o pensamento oligárquico:

"O corpo universal das idéias foi remodelado e adaptado para descrever ou explicar a condição doméstica cubana. A elite exibiu um cosmopolitismo e um refinamento insólitos para o seu tempo e lugar-tanto mais surpreendente na sua situaçāo colonial. Forçada a defender a escravidão, essa elite postulou os direitos de propriedade e a segurança da civilização - eufemismos aceitos como argumentos raciais e econômicos. Os escravos africanos eram bens. A abolição ameaçava ser a ruína e chegava-se até a arrazoar de um modo contorcido que o cativeiro era um meio de civilizar os africanos. O raciocínio e os argumentos não eram novos nem originalmente cubanos" 30 .
Descontadas certas diferenças culturais, salta à vista do historiador a formação de uma ideologia

liberal-escravista comum às três áreas em que a atividade agroexportadora se fez mais intensa a partir dos anos de 1830: o Brasil cafeeiro, o Sul algodoeiro e as Antilhas canavieiras, especialmente Cuba. Em todas, o braço escravo deu suporte ao regresso oligárquico. Essa nova decolagem da

28 MYRDAL, G. An american dilemma: the negro problem in a modern democracy. New York, Harper \& Brothers, 1944. p. 442.

29 lbid., p. 441.

30 KNIGHT, F.W. Slavery, race and social structure in Cuba during the 19 th. Century. In: TOPLIN, R.B., org. Slavery and race relations in Latin America. Connecticut, Greenwood Press, 1970. p. 221. A fusão de liberalismo, nativismo antiespanhol e defesa da escravidão em Cuba foi também observada por Eugenio D. Genovese em $O$ Mundo dos Senhores de Escravos. Rio, Paz e Terra, 1979. p. 75-80. 
economia escravista não escapou ao olho agudo de Tavares Bastos, que tudo via e tudo criticava postado no seu observatório americanófilo ${ }^{31}$.

Quanto às formações sociais andinas e platinas, onde a presença do africano tinha sido modesta ou nenhuma, construía-se, naquela altura e com as mesmas pedras de uma ideologia excludente, o que o estudioso guatemalteco Severo Martínez Peláez chamou com precisão "la patria del criollo,"32

A leitura que Franklin Knight fez do liberalismo cubano vale-se de conceitos como remodelagem e adaptação para qualificar os processos mediante os quais uma ideologia de origem européia penetrou nas mentes e nos corações do proprietário americano. Filtrou-se tão-somente o que convinha às práticas da dominação local.

Cabe uma dúvida: teria o primeiro liberalismo ortodoxo brechas que permitissem algum tipo de contemplaçāo com o trabalho escravo nas colônias?

Evidentemente, a resposta cabe aos peritos em análise dos textos de Smith, Say e Bentham. Contento-me em levantar uma ponta do véu.

Adam Smith escreveu A Riqueza das Naçōes nos anos 70 do século XVIII. A sua luta antimercantilista 6 bem conhecida. Monopólios, corporaçōes, privilegios, entraves legais ou consuetudinários: eis os seus alvos maiores. Na época, o tráfico era intenso e explorado principalmente pela marinha comercial inglesa. $O$ cativeiro mantinha-se como regra nos Estados Unidos e em todas as colônias britânicas, holandesas, francesas, espanholas e portuguesas. Smith pronuncia-se pela superioridade do trabalho assalariado que lhe parece mais lucrativo além de ético. Este, o princípio geral. Ao tratar, porém, das colônias, a sua abordagem assume um tom neutro e utilitário. Não se lê, aí, uma crítica explícita da escravidão do ponto de vista econômico. Há apenas o registro de que "a boa administração" (good management) do escravo é sempre mais rendosa do que os maus tratos:

"Mas, tal como o lucro e êxito do cultivo executado pelo gado depende muito da boa administração desse mesmo gado, também o lucro e êxito da cultura executada pelos escravos dependerá igualmente de uma boa administração desses escravos; $\mathrm{e}$, nesse aspecto, os plantadores franceses, como penso ser do consenso geral, são superiores aos ingleses" "33. Um pouco adiante, repisa: "Esta superioridade tem-se traduzido especialmente na boa administração dos seus escravos",34. Enfim: "Este tratamento nāo só torna o escravo mais fiel como ainda o torna mais inteligente $e$, portanto, mais útil",35. Os nossos prudentes ecônomos jesuítas, Antonil e Benci, não tinham recomendado coisa muito diferente aos senhores de engenho nordestinos no romper dos

Setecentos...

Uma hipótese provável é que, no seu fazer-se, entre empírico e ideal, a nova ciência das riquezas ainda não desenvolvera uma formulaçắo cabal e unívoca que desse conta também do problema da rentabilidade do escravo nas colônias. $O$ valor atribuído ao trabalho livre, cerne da Economia Política, não suprimia, de todo, o veio utilitarista e a capacidade de relatar idoneamente o que estava acontecendo, de fato, nas grandes fazendas do Novo Mundo.

Curiosa, nessa ordem de idéias, é a forma pela qual o maior divulgador de Adam Smith, Jean-Baptiste Say, enfrenta a questão crucial do cotejo do trabalho cativo com o assalariado.

31 BASTOS, T. Cartas do Solitário. $4^{\mathrm{a}}$ ed. São Paulo, Cia. Ed. Nacional, 1945. Carta XI.

32 MARTÍNEZ PELÁEZ, S. La patria del criollo. Costa Rica, Editorial Universitaria Centroamericana, 1973.

33 SMITH, A. A riqueza das nações. Lisboa, Calonste Gulbenkian, 1983. v. II, p. 137.

34 Ibid., p. 139.

35 Id. ibid., p. 138. 
Say, cujos textos foram canônicos no Brasil e nos Estados Unidos durante o século XIX, acusa a degradação a que descem senhores e escravos, e advoga a industrialização e o trabalho livre. Ao falar, porém, das colônias, procura relativizar o seu mestre Smith e os predecessores Steuart e Turgot no que toca ao custo do regime escravista; para tanto, expóe, lado a lado, as posiçōes conflitantes:

"Autores filantropos acreditaram que o melhor meio de afastar os homens dessa prática odiosa estava em demonstrar que ela é contrária a seus proprios interesses. Steuart, Turgot e Smith concordam na crença de que o trabalho do escravo custa mais caro $e$ produz menos do que o do homem livre. Seus argumentos se reduzem ao seguinte: um homem que não trabalha e não consome por conta própria trabalha o mínimo e consome o máximo que pode; não tem nenhum interesse em dedicar a seus trabalhos a inteligência e o cuidado capazes de assegurar seu sucesso; o trabalho excessivo com que é sobrecarregado diminui sua vida, obrigando seu senhor a onerosas substituições. Por último, é o servidor livre que administra a sua própria manutençăo, ao passo que cabe ao senhor a administração da manutenção de seu escravo; ora, visto ser impossivel que o senhor administre com tanta economia quanto o servidor livre, $o$ serviço do escravo deverá custar-lhe mais caro.

Os que pensam que o trabalho do escravo é menos dispendioso do que o do servidor livre fazem um cálculo semelhante ao seguinte: a manutenção atual de um negro das Antilhas, nas habitações em que são mantidos com mais humanidade, não custa mais de 300 francos. Acrescentamos a isso o juro de seu preço de compra e estimemo-lo em $10 \%$, pois se trata de um juro perpétuo. O preço de um negro comum, sendo de 2 mil francos, mais ou menos, o juro será de 200 francos, calculados por cima. Assim, pode-se estimar que cada negro custa, por ano, 500 francos a seu senhor. Ora, num mesmo país o trabalho de um homem livre custa mais do que isso. Pode cobrar por sua jornada de trabalho uma base de 5,6 ou 7 francos e às vezes até mais. Tomemos 6 francos como média e só contemos trezentos dias de trabalho por ano. Isso dá, como soma de seus salários .

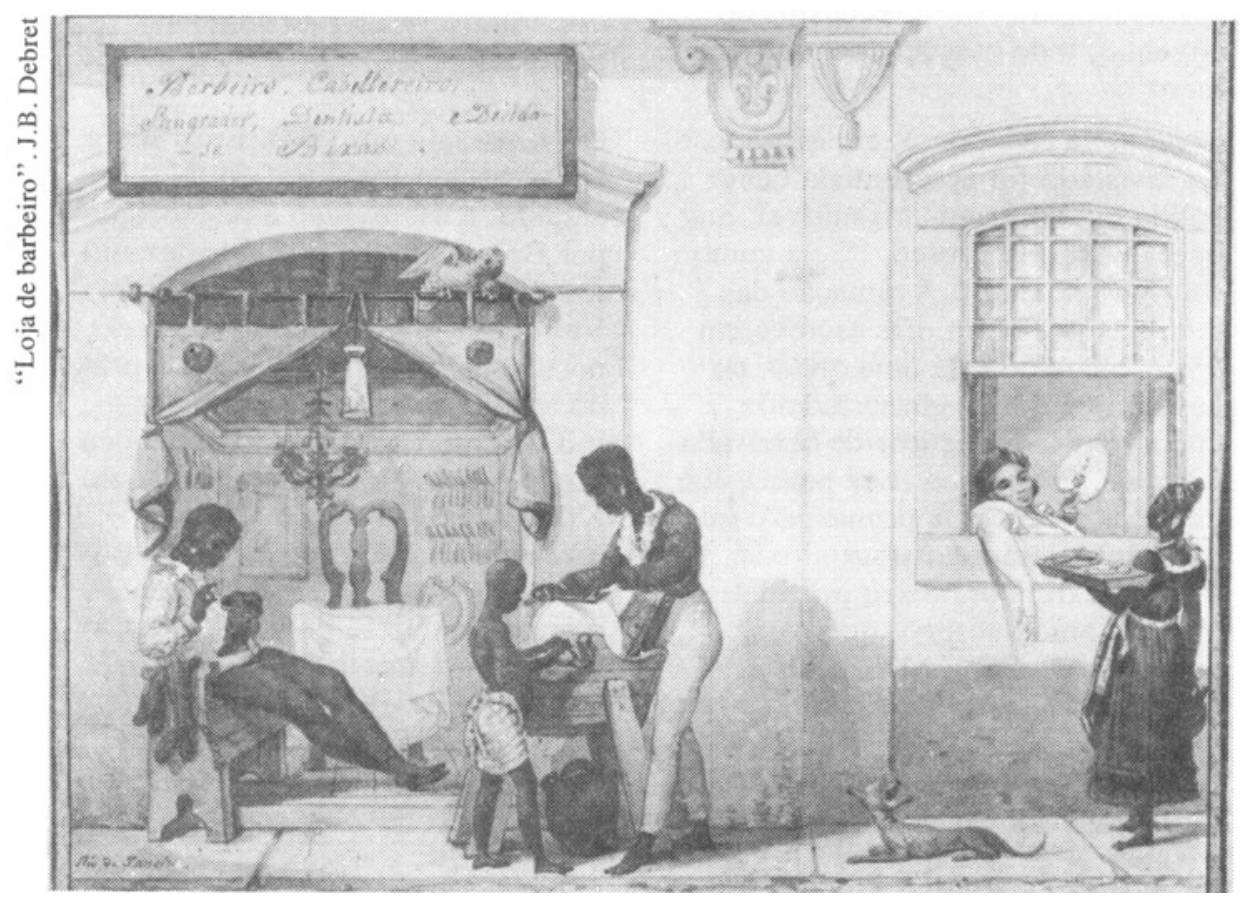


anuais, 1800 em vez de 500 francos",36.

Nos parágrafos seguintes Say reproduz, sem contestá-la, a argumentação dos escravistas ao lembrar a exigüidade real do consumo, própria do cativo ("sua alimentação se reduz à mandioca, à qual, na casa de senhores bondosos, se acrescenta de tempos em tempos um pouco de bacalhau seco"); a indigência de sua veste ("uma calça e um colete compõem todo o guarda-roupa de um negro"); a miséria de sua habitação ("seu alojamento é uma cabana sem nenhum móvel"'); enfirn, a carência desoladora a que se reduz a sua vida pessoal: "a doce atração que une os sexos está submetida aos cálculos de um senhor".

A somatória desses vários fatores resultara, objetivamente, na alta rentabilidade das plantações coloniais:

"Foi provavelmente por isso que os lucros de um engenho de açúcar eram a tal ponto exagerados que se afirmava, em São Domingos, que uma plantação, em seis anos, devia reembolsar ao proprietário o preço de compra, e que os colonos das ilhas inglesas, sgundo o próprio Smith, concordavam que o rum e o melaço bastavam para cobrir os custos do engenho, todo o açúcar sendo puro lucro,"37.

Chegado a este ponto, em que a tese escravista já foi apresentada como válida ou, ao menos, exeqüível, Say opera um corte brusco: "Seja como for, tudo mudou". A situação das Antilhas já é outra. Ele escreve em 1802, quando se dá uma queda no comércio colonial em virtude da concorrência do açúcar de beterraba europeu. $O$ trabalho livre parece-lhe alcançar a merecida primazia, o que é um trunfo para a nova ortodoxia burguesa. Embora o seu pragmatismo viscerai ainda observe que, nos engenhos de Cuba e de Jamaica, o trabalho do negro parece ser, de fato, o mais apropriado (o europeu aí não resiste, o escravo tem menos ambição e menos necessidade, o sol lá é ardente e o cultivo da cana, penoso), a linha de pensamento se volta para as teses ilustradas que, desde o último quartel do século XVIII, vinham condenando os exclusivos coloniais e o tráfico negreiro como barreiras erguidas contra o progresso e a civilização.

“A escravidão não pode sobreviver muito tempo na proximidade de nações negras libertas ou mesmo de cidadãos negros, como existem nos Estados Unidos. Essa instituição contrasta com todas as outras e terminará por desaparecer gradualmente. Nas colônias européias, ela so pode durar com o amparo das forças da metrópole, e essa, tornando-se esclarecida, terminará por retirar-lhe o apoio" 38. A profecia de Say tardou a cumprir-se, não só em relação às colônias (Cuba, Antilhas, Guiana), quanto em relaçāo aos Estados Unidos, já independentes, e ao Brasil. E em parte nenhuma o regime de cativeiro foi extinto sem contrastes, por obra espontânea dos senhores: as fugas e rebeliōes dos negros, a luta de grupos abolicionistas e a ação final do Estado foram, em todos os casos, determinantes. As oligarquias resistiram enquanto puderam.

O Traité saiu em 1803. Em 1807 a Inglaterra proíbe o tráfico. No entanto, a escravidão é restabelecida por Bonaparte depois da sangrenta revolta do Haiti. E o algodão no Velho Sul, o açúcar em Cuba e o café no Brasil fariam recrudescer a prática do trabalho escravo e estimular o tráfico com uma intensidade nunca vista. A primeira metade do século XIX foi um período febril do escravismo; e $e$ à luz desse contexto afro-americano da economia de plantagem que se pode entender a ideologia regressista dos liberais brasileiros, e não só brasileiros.

36 SAY, Jean-Baptiste. Tratado de economia política. São Paulo, Nova Cultural, 1986.

Livro I, cap. 19.

37 Ibid.

38 Id. lac. cit. 


\section{Oligarquia e Neutralização Ideológica}

Os interesses dos senhores rurais contavam com uma Carta que também servira de escudo aos moderados após a Abdicação. Antigos pais da pátria, como Evaristo e Bernardo de Vasconcelos, acabaram encalhando no areal de um sistema parlamentar de baixíssimo grau de representação:

"Nada de excessos, a linha está traçada, é a da Constituição. Tornar prática a Constituição que existe no papel deve ser o esforço dos liberais" - são palavras de um lutador histórico, Evaristo da Veiga, na sua Aurora Fluminense de 9 de setembro de $1829^{39}$. "Queremos a Constituição - não a Revolução". O mesmo homem, que a historiografia da Regência costuma opor ao regressismo, traçava com meridiana clareza a linha de separação entre o seu próprio liberalismo, que defendia, e a "democracia", que rejeitava:

O princípio da soberania popular era, no seu juízo, "contrário: $\left(1^{9}\right)$ ao fato da desigualdade, estabelecida pela natureza entre as capacidades e as potências individuais; $\left(2^{\circ}\right)$ ao fato da desigualdade de capacidades provocada pela diferença de posições; (3) à experiência do mundo que viu sempre os tímidos seguirem aos bravos, os menos hábeis obedecerem aos mais hábeis, as inferioridades naturais reconhecerem as superioridades naturais e lhes obedecerem. O princípio da soberania do povo, isto é, o direito igual dos indivíduos à soberania, e o direito de todos os indivíduos de concorrer à soberania é radicalmente falso porque, sob pretexto de manter a igualdade legítima, ele introduz violentamente a igualdade onde não existe e viola a desigualdade legítima" 40 .

Até meados do século, o discurso, ou o silêncio, de todos foi cúmplice do tráfico e da escravidão.
E qual seria o locus partidário desses liberais que, exatamente como pensava Evaristo, tinham por legítima a desigualdade?
A resposta deve buscar-se na mutante biografia política dos moderados de 31 , dos regressistas de 36 , dos conservadores dos anos 40 , dos conciliadores e ligueiros dos anos 50 .

Nabuco de Araújo foi primeiro conservador, depois conciliador e ligueiro, enfím neoliberal. Paraná, Torres Homem e Rio Branco foram primeiro liberais, depois conservadores de centro. Zacarias, Saraiva, Paranaguá e Sinimbu, primeiro conservadores, depois liberais. Vasconcelos, Paulino de Sousa e Rodrigues Torres, primeiro moderados, depois cardeais de conservadorismo. Para todos, e pouco importa aqui o nome do grupo, a própria noção de liberdade fora uma herança transmitida pela geração que os precedera entre 1808 e 1831. Assentados nessa plataforma, convinha-lhes a facção eleitoral que, em cada conjuntura, melhor os resguardasse. É o acerto da frase sardônica: "Nada mais parecido com um saquarema do que um luzia no poder".

Até meados do século, o discurso, ou o silêncio, de todos foi cúmplice do tráfico e da escravidão. O seu liberalismo, parcial e seletivo, não era incongruente: operava a filtragem dos significados compatíveis com a liberdade intra-oligárquica $e$ descartava as conotações importunas, isto é, as exigências abstratas do liberalismo europeu que não se coadunassem com as particularidades da nova nação.

Um testemunho abalizado do que chamo de filtragem ideológica é o de Eusébio de Queirós, cujo nome está associado à lei que proibiu finalmente o tráfico em 1850, depois de tantos enfrentamentos com o governo britânico. Falando do aspecto moral do comércio negreiro, Eusébio, ministro da Justiça e ex-chefe de Polícia do Rio de Janeiro, procede a uma descriminalização dessa atividade:

39 TARQÜÍNIO de SOUSA. Evaristo da Veiga, op. cit., p. 61.

$40 \mathrm{Em} O$ Independente, 14 de março de 1832, apud Augustin Wernet, Sociedades políticas (1831-32). São Paulo, Cultrix, 1978. p. 67. 
"Sejamos francos: o trafico, no Brasil, prendia-se a interesses, ou para melhor dizer, a presumidos interesses dos nossos agricultores; e num país em que a agricultura tem tamanha força, era natural que a opinião pública se manifestasse em favor do tráfico; a opiniāo pública que tamanha influência tem, não só nos governos representativos, como até nas próprias monarquias absolutas. $O$ que há pois para admirar em que os nossos homens políticos se curvassem a essa lei da necessidade? O que há para admirar em que nós todos, amigos ou inimigos do tráfico, nos curvássemos a essa necessidade?

Senhores, se isso fosse crime, seria crime geral no Brasil; mas eu sustento que, quando em uma naçāo todos os partidos políticos ocupam o poder, quando todos os seus homens políticos têm sido chamados a exercê-lo, e todos eles são concordes em uma conduta, é preciso que essa conduta seja apoiada em razóes muito fortes; impossivel que ela seja um crime e haveria temeridade em chamá-la um erro" $" 41$.

O tráfico fora suspenso, mas a sua apologia ainda se fazia presente na boca daqueles mesmos que tinham sido obrigados a proibi-lo de vez.

Uma posição mais crua se dá ao olhar do historiador quando este se volta do discurso oficial para um depoimento sem rebuços, feito pelo dono de uma velha casa comercial do Rio, amargamente ressentido com as emissões bancárias que jorraram depois da extinção do tráfico (estaria ele envolvido no mercado negreiro?):

"Antes bons negros da costa da África para felicidade sua e nossa, a despeito de toda a mórbida filantropia britânica, que esquecida da sua própria casa deixa morrer de fome o pobre irmão branco, escravo sem senhor que dele se compadeça, $e$ hipócrita ou estólida chora, exposta ao ridículo da verdadeira filantropia, $o$ fardo do nosso escravo feliz. Antes bons negros da costa da África para cultivar os nossos campos férteis do que todas as teteias da rua do Ouvidor, do que vestidos de um conto e quinhentos mil réis para as nossas mulheres; (...) do que, finalmente, empresas mal avisadas muito além das legítimas forças do país, as quais, perturbando as relaçōes da sociedade, produzindo uma deslocação de trabalho, têm promovido mais que tudo a escassez e alto preço dos víveres"42.

José de Alencar, um dos campeōes do status quo nos debates de 1871 , lamentaria, em estilo menos brutal, os males da especulação financeira, do jogo bolsista e do luxo corruptor que o papel-moeda fácil trazia aos costumes da Corte. E identificaria o ritmo lento e pesado da velha economia (leia-se: o pleno domínio do tráfico) com os seus próprios valores de honra e austeridade. É a suma da peça $O$ Crédito, levada à cena em 1857, e que pode ser interpretada como a metáfora do nosso capitalismo acanhado. Retomando a questão em uma das suas Cartas a Erasmo, dirigida ao mentor financeiro do Império, o visconde de Itaboraí, Alencar ressaltaria a conveniência de aplicar-se o novo crédito bancário à produção agrícola, ou seja, a necessidade de se estreitarem os vínculos entre o poder monetário do Estado e a economia do latifúndio. $O$ escritor alegava, em favor do seu projeto, a razão de ser o Brasil "um país novo, onde se pode dizer que a grande propriedade ainda está em gestação"... A inflação, que, para a ortodoxia de Itaboraí, era um mal, subiria ao nível de mal necessário desde que beneficiasse o senhor de terras. Reprodução e autodefesa com o suporte dos cofres públicos: limites do que se poderia chamar a ideologia dominante pós-colonial. Nessa concepção, o pecado da livre-emissão só era julgado mortal quando cometido fora do legítimo consórcio com o interesse da "grande

41 Apud NABUCO, J. O Abolicionismo, op. cit.

42 Apud NABUCO, J. Um Estadista ... op. cit., p. 217-18. 
propriedade'. Alencar, nas mesmas Cartas, ainda verbera os impostos e a "empregocracia", e condena, nos mesmos termos de Cairu e

Vasconcelos, a proteção a "fábricas e manufaturas não existentes nem sonhadas no país". Um liberalismo pre-industrial coerente ajustava-se às nossas rotinas oligárquicas.

Liberalismo ou conservadorismo? A neutralização é vivida e formulada ao longo dos anos 50. Já não há lugar para profissões de fé ideológico-partidárias, tal é a unidade de valores subjacente aos interesses de facção. $O$ senador Nabuco de Araújo, em pleno trânsito da Conciliação para a Liga, busca entender as causas desse indiferentismo doutrinário pelo qual o nome "liberal" traduzia um conteúdo conformista; e as identifica naquilo que lhe parece ser a homogeneidade do corpo social brasileiro:

"Eu concedo que em uma sociedade, onde há classes privilegiadas, onde existem interesses distintos e heterogêneos, onde ainda domina o princípic do feudalismo, aí haja, como na Inglaterra, partidos que sobrevivem aos séculos; mas onde os elementos são homogêneos, como em nossa sociedade, na qual não há privilégios, na qual os partidos representam somente princípios de atualidade que todos os dias variam e se modificam, aí os partidos são precários",43.

O discurso, proferido em 13 de junho de 1857 , deixa de nos parecer escandaloso, se entendermos pela expressão nossa sociedade, não o povo brasileiro em geral, mas apenas aquele círculo de homens elegiveis economicamente qualificados e, portanto, aptos para a ação política nos termos da Carta de 1824. Dentro desse espaço fechado era, de fato, pertinente indagar: para que partidos ideol6gicos conflitantes, se tudo se reduzia a um loteamento de cargos, influências e honrarias?
O marquês do Paraná, chefe do gabinete conciliador a que Nabuco servia, pensava da mesma maneira quando reconhecia no "estado em que se achava a sociedade" o móvel da fusão dos antigos liberais com os conservadores de sempre.

É também verdade que esse liberalismo corporativo assumia às vezes um tom exaltado quando alguma conjuntura o encostasse à margem do poder. Aparecia então a retórica democrática feita de puro ressentimento pessoal ou grupal, que engana, mas por breve tempo. Um exemplo forte se tem no Libelo do Povo, de Timandro, pseudônimo de Sales Torres Homem, diatribe contra o poder pessoal do Imperador. $O$ panfleto foi considerado, em 1849 , radical, mas o seu alvo não era a efetiva opressão política do regime: investia apenas contra a Casa de Bragança, descompunha a família reinante e, por tabela, a tirania portuguesa. $O$ autor passou-se mais tarde para as fileiras palacianas e foi agraciado com o título de visconde de Inhomirim. Desses liberais dirá um filho de mulher africana nas Trovas Burlescas:

"Se ardente campeão da liberdade Apregoa dos povos a igualdade, Libelos escrevendo formidáveis, Com frase de peçonha impenetráveis: Já do céu perscrutando alta eminência.

Abandona os troféus da inteligência, Ao som d'argém (argent?) se curva, qual vilão, O nome vende, a glória, a posição:

É que o sábio, no Brasil, só quer lambança

Que possa empantufar a larga pança!"44.

Na Província, truncado a ferro e fogo o ciclo das revoltas, o quadro partidário também estagnou em um adesismo larvar, sintoma da sua dependência para com os ditames da Corte. Assim ironiza as facções de sua

43 NABUCO, J. Um Estadista ... op. cit., p. 319.

44 GAMA, L. (Getulino). Primeiras trovas burlescas. $3^{\text {a }}$ ed. São Paulo, Tip. Bentley Junior \& Comp, 1904. 
terra maranhense um jornalista de pulso, Joāo Francisco Lisboa:

"Em geral... têm sido favoráveis ao governo central, e so lhe declaram guerra, quando de todo perderam a esperança de obter o seu apoio contra os partidos adversos que mais hábeis ou mais felizes souberam acareá-lo para si. Quando o Exmo. Sr. Bernardo Bonifácio, importunado das recíprocas recriminações e dos indefectíveis protestos de adesão e apoio destes ilustres chefes, os interrogava ou sondava apenas, respondiam eles, cada um por seu turno: - A divisa dos Cangambás é Imperador, Constituição e Ordem. Os Mossorocas só querem a Constituição com o Imperador, únicas garantias que temos de paz e estabilidade. Os Jaburus são conhecidos pela sua longa e inabalável fidelidade aos princípios de ordem e monarquia; o Brasil não pode medrar senão à sombra protetora do Trono. Vêm os Bacuraus por derradeiro e dizem: Nós professamos em teoria os princípios populares; mas somos assaz ilustrados para conhecermos que o estado do Brasil não comporta ainda o ensaio de certas instituiçōes. Aceitamos pois sem escrúpulos a atual ordem de cousas, como fato consumado, uma vez que nos garanta o gozo de todas as regalias dos cidadãos. Estamos até dispostos a prestar-lhe a mais franca e leal cooperação" (Jornal de Timon: "Partidos e Eleições no Maranhão").

O teor informativo do texto nos dá a imagem nítida da situação no interior sob o domínio do interesse oligárquico que vários clãs partilhavam. Mas a perspectiva já é crítica e, no seu movimento, dialética, pois aponta para um liberalismo superior que, naquela altura, mal se vislumbrava, mas que pulsava e, cedo ou tarde, irromperia.

\section{A Formação do Novo Liberalismo \\ "O lavrador brasileiro deve reconhecer que chegou já, por imposição do destino, ao regime do trabalho assalariado." \\ Quintino Bocayuva, A Crise da Lavoura, 1868.}

"As instituições existem, mas por e para $30 \%$ dos cidadāos. Proponho uma reforma no estilo político. Não se deve dizer: "consultar a nação, representantes da nação, os poderes da naçāo'; mas 'consultar os 30\%, representantes dos $30 \%$, poderes dos $30 \%$ '. A opiniāo pública é uma




metáfora sem base; há só a opiniāo dos 30\%."

Machado de Assis, História de Quinze Dias, crônica, 15 de agosto de 1876 .

"Ou o campo ou as cidades; ou a escravidão ou a civilização; ou os Clubes da Lavoura ou a imprensa, os centros intelectuais, a mentalidade e a a moralidade esclarecida do país."

Joaquim Nabuco, "O terreno da luta", Jornal do Comércio, 19 de julho de 1884 .

Se o caráter principal do acontecimento é poder situar-se com precisão nas coordenadas do espaço e do tempo, o mesmo não se dá com o processo ideológico. Este não surge de improviso ou por acaso, de um dia para o outro. Sua matéria-prima são idéias afetadas de valores, e idéias e valores se formam lentamente, com idas e vindas, no curso da história, na cabeça e no coração dos homens. No entanto, como a ponta do iceberg é claro indício da existência de massas submersas cuja profundidade não se pode calcular a olho nu, também certas situações, rigorosamente datadas, ao se armarem, servem de pista ao leitor de ideologias para detectar correntes que vêm de longe. A data exerce, então, o papel de signo ostensivo de uma viragem.

A historiografia é unânime em assinalar o ano de 1868 como o grande divisor de águas entre a fase mais estável do Segundo Império e a sua longa crise que culminaria, 20 anos mais tarde, com a Abolição e a República.

A data de 1868 aqui importa porque nela se ouve um toque de reunião (o estilo hugoano do tempo inspiraria imagens de "clarinada" e "clangor de trompas") dos liberais, então revoltados com o gesto abrupto de Pedro II que acabara de demitir o gabinete de Zacarias de Góis, majoritário no Parlamento.

A decisão, embora traumática, nāo feria a lei maior, figurando entre as atribuiçōes do Poder Moderador. Mas o seu efeito foi o de um catalisador de de forças dispersas. E são as ressonâncias do ato que compõem a nova situação e valem como aquela ponta do iceberg. A reação dos políticos, da imprensa, dos intelectuais, dos centros acadêmicos em todo o País, aparece como uma cadeia de elos significativos e remete pergunta pelos valores em causa. Que liberalismo é esse que sai a campo em busca de um programa de reformas amplas, e já não se sente um mero ventríloquo das dissidências oligárquicas?

A crise de 68 é o momento agudo de um processo que, de 65 a 71, levou à Lei do Ventre Livre. Analisada por esse ângulo, é uma crise de passagem do Regresso agromercantil, emperrado e escravista, para um reformismo arejado e confiante no valor do trabalho livre. Essa leitura dos fatos tem a sua verdade, mas é preciso que se distinga com clareza a vertente liberal-radical (expressão que aparece, pela primeira vez, em 1866 , na folha $A$ Opinião Liberal), do conjunto bastante hibrido que foi o Partido Liberal até a abolição completa em 1888.

Nos últimos decênios do Império as tendências progressistas circulam pelo Partido Liberal e pelo Republicano, mas não coincidem perfeitamente nem com um nem com o outro. E haverá resistências conservadoras, e até escravistas, em ambos os grêmios 45 .

A história do novo liberalismo, para continuar usando a expressão de Joaquim Nabuco, pode ser apreendida tanto no ritmo da longa duração quanto no das conjunturas.

Pelo primeiro, que contempla o nível dos sistemas, a relação se faz entre a nova corrente ideológica, visível desde os anos 60, e o dinamismo econômico e social que a extinção do tráfico instaurou no País já a partir de 1850. Os capitais, que montavam em cerca de 16 mil contos, liberados para afluir ao comércio, à manufatura, à

45 SANTOS, J.M. A política geral do Brasil. São Paulo, J. Magalhães, 1930. p. 133-54. (esp. cap. VIII, "A Abolição"). 
rede de transportes ou ao puro jogo da Bolsa, na verdade aceleraram o processo de urbanização e o emprego do trabalho assalariado. A situação foi alimentada, estruturalmente, pela contínua expansão agroexportadora que a demanda internacional sustentou até o fim do século: a existência de um mercado interno e de um pólo urbano em desenvolvimento na região Sudeste foi a condição necessária para a emergência de valores liberais mais amplos do que os professados pelo discurso intra-oligárquico. "Ou o campo ou as cidades; ou a escravidão ou a civilização" 46 .

Ainda em termos de infra-estrutura: na região nordestina, esvaziada rapidamente pelo tráfico interno, que vendia o braço negro aos fazendeiros do Sul, o trabalho sob contrato já se tornara fato consumado entre os anos 60 e 70 . Notava, então, o primeiro ideólogo de nossa modernização capitalista, Tavares Bastos:

"Apontarei o fato de já estarem em Pernambuco, no Rio Grande do Norte e na Paraíba, os homens livres, admitidos por salário ao trabalho dos próprios engenhos e plantações de açúcar. Digo o mesmo do Ceará quanto à nascente lavoura de café. Não obstante a cólera e a exportação de escravos para o Sul, a produção daquelas províncias não tem diminuído; a do Ceará tem aumentado muito. A sua agricultura vai-se melhorando, introduzindo o arado e aplicando os motores a vapor. $\mathrm{O}$ senhor de engenho, nalgumas localidades, quase que se vai tornando mero fabricante de açúcar, sendo piantada por vizinhos, ou lavradores agregados, grande parte da cana moída no engenho, o que é uma divisão econômica do trabalho" 47 . Uma das tônicas das Cartas do Solitário, escritas a partir de 1861 para o Correio Mercantil, era a necessidade e a superioridade do trabalho livre.

Um pensamento liberal moderno, em tudo oposto ao pesado escravismo dos anos 40, pôde formular-se tanto entre políticos e intelectuais das cidades mais importantes, quanto junto a bacharéis egressos das famílias nordestinas que pouco ou nada podiam esperar do cativeiro em declínio.

O novo liberalismo será urbano, em geral; e será nordestino, em particular $^{48}$.

Quanto às tendências ideológicas dos fazendeiros de café tidos por mais modernos (principalmente os do Novo Oeste paulista), seriam, na verdade, muito peculiares. Neles, o que parece, à primeira vista, antiescravismo, é, a rigor, imigrantismo. $\mathrm{O}$ fato de terem subido ao poder com a proclamação da República deu-lhes uma posição hegemônica que lhes permitiria resolver a questão do trabalho rural em termos próprios, estreitos e pragmáticos. Os seus planos tangenciaram, mas não se confundiram com as idéias reformistas que vão de Tavares Bastos a Rebouças, de Quintino Bocayuva a Joaquim Nabuco.

Distinguir entre correntes de opinião e grupos partidários se faz uma necessidade aguda quando se passa de uma perspectiva de longa duração - a que corre entre os anos 60 e o fim do Império - para a análise miúda das ações e reações gremiais. Nos vaivéns da petite histoire, que o leitor dos Anais do Parlamento poderá acompanhar, não é raro ver membros do Partido Conservador, aliciados pela Coroa, defender a libertação dos nascituros de mulher escrava (como o propuseram os gabinetes do marquês de São Vicente e do visconde de Rio Branco), ou surpreender atitudes retrógradas entre os filiados ao
Quanto às tendências ideológicas dos fazendeiros de café tidos por mais modernos (principalmente os do Novo Oeste paulista), seriam, na verdade, muito peculiares. Neles, o que parece, à primeira vista, antiescravismo, é, a rigor, imigrantismo.

46 NABUCO, J. O terreno da luta. Jornal do Comércio, 19 jul., 1884.

47 BASTOS, T. Cartas do Solitario, op. cit., p. 268.

48 "Na região nordestina de Pernambuco, por exemplo, onde o trabalho escravo predominara nas fazendas na época da Independência, já na década de 1870 o trabalho livre tornara-se mais importante" (EISENBERG, Peter L., A abolição da escravatura: o processo nas fazendas de açúcar em Pernambuco. in Estudos Econômicos, São Paulo, 2 (6): 181, dez. 1972.) 
Partido Liberal, como as do mineiro Martinho Campos, que mais de uma vez se declarou "escravocrata da gema".

Assim se deu também na questão da eleiçāo direta, reforma grata aos radicais de 60: as opiniōes se foram repartindo conforme os interesses regionais e clânicos e sem levar em conta a cor partidária. Os velhos liberais moderados, que afinal a empreenderam, como Sinimbu e Saraiva, apoucaram-na a tal ponto que, mantido o censo pecuniário e literário, reduziam o eleitorado a $1 / 20$ da população; o que provocou reaçōes indignadas em Silveira Martins, Saldanha Marinho e José Bonifácio, o moço, este último mestre de dois estreantes no Parlamento, Rui Barbosa e Joaquim Nabuco. A intervenção do Andrada na sessão de 28 de abril de 1879 virou matéria de antologia democrática:

"Neste país, a pirâmide do poder assenta sobre o vértice em vez de assentar sobre a base".

Ou entāo, fazendo sátira à cláusula oficial que proibia $o$ voto ao analfabeto:

"Esta soberania de gramáticos é um erro de sintaxe política (apoiados e risos). Quem é o sujeito da oração? (Hilaridade prolongada). Não é o povo? Quem é o paciente? Ah! descobriram uma nova regra: $\epsilon$ não empregar o sujeito (hilaridade)"49.

Mas qual o corte que separou, no fundo, os dois liberalismos? Se o tema da eleição direta foi o mais vistoso, o modo de tratar a questâo servil terá cavado um divisor de águas mais largo: este $\epsilon$ o olhar retrospectivo de Joaquim Nabuco, que teoriza a história do Império à luz da sua prática abolicionista. A memória do lutador traz ao primeiro plano da crise institucional de 1868 as inquietudes sociais do pai, o Senador: "Eu traduzia documentos do Anti-Slavery Reporter para meu pai que, de 1868 a 1871 , foi quem mais influiu para fazer amadurecer a idéia da emancipação" 50 .

A clivagem $e$ fundamental, e assim se mantém ate a hora em que a campanha se faria irreversível e o abolicionismo tomaria o vulto de um verdadeiro partido dentro dos demais:

“"Em 1884 deu-se a conversão do partido liberal e em 1888 a do partido conservador" 51 .

Joaquim Nabuco tem plena consciência do contraste do novo pensamento com o velho discurso regressista ou conciliador. São dois blocos históricos que incluem toda a sociedade civil e se manifestam sob a forma difusa da opinião pública.

"A opiniāo, em 1845, julgava legítima e honesta a compra de africanos transportados traiçoeiramente da África, e introduzidos por contrabando no Brasil"52.

No artigo "A reorganizaçăo do Partido Liberal", volta a ser incisivo ao expor a dialética do liberalismo em face da escravidão:

"Af está uma profunda divergência entre o novo liberalismo e $o$ antigo, $o$ qual ainda existe, em toda a sua força, mas felizmente tendo atingido ao seu limite de crescimento, e devendo portanto declinar e não mais expandir-se. A primeira grande divergência foi essa do abolicionismo, que opôs ao antigo espírito político do partido o espírito verdadeiramente popular, e substituiu a luta das teses constitucionais sem alcance e sem horizonte pela luta contra os poderosos privilégios de classe, contrários ao desenvolvimento da nação. Pela primeira vez então o Partido Liberal saiu do terreno das

49 Apud HOLANDA, S.B. Do Império d̀ República. 4ª ed. São Paulo, Difel, 1985. p. 204.

50 NABUCO, J. Minha formação. Rio, José Olympio, 1957. p. 34.

51 lbid., p. 201.

52 Id. ibid., p. 59. 
discussóes escolásticas, que so interessavam à classe governante, para entrar no terreno das reformas sociais, que afetam as massas inconscientes do povo"53.

Não se tratava, pois, de um simples "renascimento liberal", mas de uma ideologia de oposição que metia a sua cunha dentro do próprio partido. Uma forma conscientemente moderna de pensar os problemas do trabalho e da cidadania. Se ao observador da História Ocidental essa apologia do assalariado poderá parecer um tanto retardatária, é porque o nosso capitalismo também era, na palavra de um seu intérprete feliz, um "capitalismo tardio" 54 . O autor da expressão, o economista João Manuel Cardoso de Melo, estudando os limites internos à expansão do antigo regime, concluiu que "os últimos anos da década de Sessenta marcam a crise da economia mercantil-escravista cafeeira. E, como veremos, o momento decisivo da crise da economia colonial",55.

A resposta à crise veio tanto dos movimentos abolicionistas urbanos (e nordestinos) quanto, logo depois, da política imigrantista dos fazendeiros de São Paulo: as motivações sociais e morais eram diferentes entre si, mas, por sendas opostas, concorreram para o fim do cativeiro.

De qualquer modo, a ruptura do equilíbrio político em 1868 não poderia ter levado a medidas radicais pelo simples fato de o projetó imigrantista não estar, àquela altura, amadurecido, mas apenas idealizado por alguns homens públicos mais sensíveis à escassez, real ou potencial, da mão-de-obra. As medidas práticas viriam 2 ou 3 lustros mais tarde.

Os textos polêmicos que exprimem o inconformismo liberal de 1868-69 ainda nāo trazem como punctum dolens único a questão do trabalho; esta aparece como item de um programa no qual a ênfase é dada à reforma eleitoral. $O$ novo liberalismo, de extração urbana, quer dar voz e voto aos seus virtuais eleitores:

"Atualmente a aspiração mais ardente de todos os brasileiros esclarecidos, como tem sido de todos os partidos de oposição, é liberdade ampla de eleição; pronunciamento franco da opiniāo do país nos comícios eleitorais" - diz em carta pública José Antônio Saraiva ao conselheiro Nabuco de Araújo que lhe pedira sua "opinião acerca das reformas que devem figurar no programa liberal" 56.

A conjuntura excitava o debate preferencial sobre o tema da representação. A derrubada do ministério Zacarias e a nomeação de um gabinete confiado ao ultra visconde de Itaboraí tinham posto a nu a força real do Poder Moderador e a impotência dos deputados; em suma, a precariedade de todo o sistema partidário.

“Que o Sr. D. Pedro II tem de fato um poder igual ao de Napoleão III, é outra verdade de que eu estou profundamente convencido. A constituição francesa, porém, $\epsilon$ a base do poder daquele monarca, ao passo que o falseamento do voto é a origem do excessivo poder do Imperador do Brasil", acusava Saraiva.

Mas convém atentar para um sintoma de nova mentalidade. $O$ protesto dos liberais não se esgotou no clamor por eleições diretas e livres de tropelias provocadas pelos coronéis. Nas ondas dessa "maré democrática" também se impõe e se move a idéia do trabalho assalariado como projeto a médio prazo. Não é ainda a reivindicação primeira. Falta-lhe concreção temática; falta a resposta à grande pergunta: como substituir, aqui e agora, o braço negro, sustento exclusivo do café? A liberdade dos nascituros mediante indenização é ainda a proposta-limite. Mas, de

53 Em O País, 9 de dezembro de 1886; transcrito por Paula Beiguelman, Joaquim Nabuco. Política. São Paulo, Ática, p. 136-7.

54 CARDOSO de MELO, J.M. O Capitalismo tardio. São Paulo, Brasiliense, 1982.

55 Ibid., p. 72.

56 O Centro Liberal. Ed. Senado Federal, Brasília, 1979. p. 44. 
qualquer modo, o princípio do contrato livre reponta e será incontornavel em mais de um contexto.

Na carta de Saraiva: "Do falseamento das eleições derivam todas as nossas dificuldades, bem como do trabalho escravo todos os nossos atrasos industriais. São estes, pois, em meu humilde conceito, os dois pontos cardeais para que devem convergir completamente a atenção e o esforço do Partido Liberal.

Com a eleição livre, com a desaparição do elemento servil, e com a liberdade de imprensa que já possuímos, o Brasil caminhará seguro para seus grandes e gloriosos destinos, e em um futuro não muito remoto colocar-se-á entre as nações mais adiantadas.

Com a escravidão, porém, do homem e do voto, não obstante a liberdade de nossa imprensa, continuaremos a ser, como somos hoje, menosprezados pelo mundo civilizado, que não pode compreender se progrida tâo pouco com uma natureza tão rica".

A polaridade semântica é esta: nossos atrasos vs. naçōes mais adiantadas. A consciência aguda do atraso se forma de Tavares Bastos a Nabuco, de Rebouças a Rui Barbosa, em função do contraste entre cativeiro e trabalho livre. Com os olhos postos na Inglaterra e nos Estados Unidos os nossos políticos progressistas exercerão uma crítica cerrada ao regime.

No Manifesto do Centro Liberal, lançado em março de 1869, além da radiografia dos abusos que se

A polaridade semântica é esta: nossos atrasos vs. naçōes mais adiantadas.

A consciência aguda do atraso se forma de Tavares Bastos a Nabuco, de Rebnuças a Rui Barbosa, em

função do contraste entre cativeiro e trabalho livre. seguiram à subida dos conservadores, avulta a exigência de reformas já então vistas como o necessário meio termo entre o regresso e a revolução:

"Ou a reforma.

Ou a revolução.

A reforma para conjurar a revolução.

A revolução, como conseqüência necessária da natureza das coisas, da ausência do sistema representativo, do exclusivismo e oligarquia de um só partido.

Não há que hesitar na escolha:

A reforma!

E o País será salvo".

Assinavam: José Thomaz Nabuco de Araújo, Bernardo de Souza Franco, Zacarias de Góis e Vasconcellos, Antonio Pinto Chichorro da Gama, Francisco José Furtado, José Pedro Dias de Carvalho, João Lustosa da Cunha Paranagua, Teofilo Benedicto Benedicto Ottoni e Francisco Octaviano de Almeida Rosa ${ }^{57}$.

Qual o conteúdo dessa reforma salvadora? O programa se formulou em outro texto, subscrito pelos mesmos nomes e publicado inicialmente pelo Diário da Bahia em 16 de maio de 1869. Compóe-se de cinco pontos, dos quais o último $e$, literalmente,

Emancipação dos escravos, seguido por este comentário restritivo: "consistindo na liberdade de todos os filhos de escravos que nascerem desde a data da lei, e na alforria gradual dos escravos existentes, pelo modo que será oportunamente declarado".

Pode-se dizer que até a deflagração da campanha abolicionista na Câmara e na imprensa, entre 1879 e 1880 , as bandeiras liberais serão precisamente estas: a liberdade dos nascituros mediante ressarcimento e emancipação gradual dos escravos restantes.

Mais adiante, o Manifesto lança um parágrafo tático que denuncia o receio de dividir o novo partido em alas divergentes, o que tornaria difícil a ação do Centro Liberal em uma hora em que a unidade anticonservadora se impunha:

“A emancipação dos escravos não tem íntima relação com o objeto principal do programa, limitado a uma certa ordem de abusos; é porém uma grande questão da atualidade, uma exigência imperiosa e urgente da civilização desde que todos os Estados aboliram a escravidão, e o Brasil é o único país

57 Ibid., p. 1000. 
cristão que a mantém, sendo que na Espanha esta questão é uma questão de dias.

Certo, é um dever irserente à missão do Partido Liberal, e uma grande glória para ele a reivindicação da liberdade de tantos milhares de homens que yivem na opressão e na humilhação" 58 .

As tintas renovadoras do programa terão sido obra da ala móvel do partido. Refletem o pensamento de Te6filo Ottoni, que dirigira uma experiência de migração alemã no Vale do Mucuri, de Francisco Octaviano, de Tavares Bastos, de Nabuco de Araújo. A evolução ideológica do último, que o filho acompanhou passo a passo em $U m$ Estadista do Império, faz supor que alguma coisa de mais profundo acontecera desde o seu cauto compromisso com a política senhorial até a busca de uma alternativa moderna. A nova posição, de que foi paradigma o "discurso de sorites" proferido em 17 de julho de 1868, abriu, conforme o juízo enaltecedor de Joaquim Nabuco, “a fase final do Império"59.

A oração assesta um golpe de mestre no estreito formalismo jurídico do sistema, precisamente no trecho em que distingue entre legalidade e legitimidade das instituições. $O$ assunto da polêmica era, como se sabe, a recente nomeação por Pedro II de um gabinete conservador sem respaldo na Câmara: ato legal, pois cabia à Coroa escolher e demitir ministérios; mas ato ilegítimo, porque a maioria absoluta do Parlamento era liberal.

Feita com clareza a distinção, em nome da consciência e da justiça, Nabuco de Araújo também a aplica à instituição do cativeiro:

“A escravidão, verbi gratia, entre nós $\epsilon$ um fato autorizado pela lei, $\epsilon$ um fato legal, mas ninguém dirá que é um fato legítimo, porque $\epsilon$ um fato condenado pela lei divina, $\in$ um fato condenado pela civilização, é um fato condenado pelo mundo inteiro" 60 .

O que mudara, substancialmente?

O novo liberalismo já tem plenas condições mentais para dizer que a escravidão, ainda que formalmente legal, é ilegítima. O mesmo Nabuco, quatorze anos antes desse discurso, pensara e agira diversamente. Em 1854, quando ministro da Justiça do gabinete conciliador de Paraná, ele tinha pactuado com uma infame decisão oficial que prescrevera, isto $\epsilon$, cancelara os efeitos da lei de 7 de novembro de 1831 , pela qual a Regência conviera em declarar livres os africanos aqui desembarcados depois dessa data. O ministro Nabuco não só aceitara aquela aberta violação da lei de 1831 como a defendera em termos de razâo de Estado, aconselhando o presidente da província de São Paulo a lançar mão dela no caso particular de um africano, de nome Bento, trazido clandestinamente ao Brasil após a cessação legal do tráfico. $O$ escravo tinha fugido e, ao ser apreendido pela polícia, foi liberado pelo juiz de direito que conseguira apurar a data da sua entrada. Nabuco de Araújo, porém, justifica os "direitos do senhor" que o reclamava, alegando "o bem dos interesses coletivos da sociedade, cuja defesa incumbe ao governo", e remata: "Não convém que se profira um julgamento contra a lei, mas convém evitar um julgamento em prejuízo desses interesses, um julgamento que causaria alarma e exasperação aos proprietários" $" 61$.

Em 1854, legítimo era, para o ministro Nabuco, o interesse dos fazendeiros; e legal, mas infringível, a lei que protegia a liberdade do africano. Em 1868, ao contrário, legítima passa a

58 Id. ibid., p. 102.

59 Um Estadista... op. cit., p. 662.

60 Id. ibid.

61 Trata-se de uma carta confidencial do ministro Nabuco a Saraiva quando este presidia à província de São Paulo. A data é 22 de setembro de 1854 (Um Estadista ... op. cit., p. 207). 
ser, no seu discurso, a liberdade dos filhos de mulher escrava, e apenas legal, logo passível de reforma, o direito do senhor à propriedade do nascituro.

$A$ inversão do critério tem um sentido forte: o liberalismo de 68 já não e o liberalismo de 54. O conteúdo concreto da legitimidade, que $e$ o coraçâo dos valores de uma ideologia política, tinha mudado. E o motor dessa transformação fora o ideal civilizado do trabalho livre; não ainda a sua necessidade absoluta e imediata, mas o seu valor. Nesse mesmo ano-chave de 1868 publicava Quintino Bocayuva (liberal pro-republicano) um follheto sobre $a$ crise da lavoura, em que advogava uma política de emigração chinesa a curto prazo, subsidiada pelo Estado 62 .

Dar à batalha parlamentar de 1871 foi um passo que os novos liberais deram com Exito e sem vínculo obrigado com a sua cor partidária. Entre os 61 votantes a favor da Lei do Ventre Livre, bem como entre os 35 que lhe foram contrários, figuravam membros de ambos os partidos políticos do Império. O café paulista votou contra. A mentalidade empresarial dos fazendeiros do Oeste, já em plena expansāo, não era, porém, tão moderna, lúcida e progressista como a supós a historiografia paulista do século XX. Era ainda escravista.

\section{Reforma e Abolição}

No contexto maior do novo liberalismo, que dará o tom ideol6gico ao fím do Império, nāo é exato falar apenas de um abolicionismo. O plural e mais consentâneo com a variedade de pontos de vista e de interesses específicos que, afinal, concorreram para a Lei Áurea na forma pela qual se promulgou, e sem a indenização tão reclamada ainda nos anos $\mathbf{8 0}$.

Joaquim Nabuco distinguiu, em Minha Formação, cinco forças entre os agentes daquele desfecho:
1) os abolicionistas que fizeram a campanha no Parlamento, na imprensa e nos meios acadêmicos;

2) os militantes da causa, abertamente empenhados em ajudar as fugas em massa e instruir os processos de alforria;

3) os proprietćrios de escravos, sobretudo nordestinos e gaúchos, que se puseram a libertá-los em grande número nos últimos anos do movimento;

4) os homens públicos (Nabuco os chama generosamente "estadistas") mais ligados ao governo, que, a partir da Fala do Trono de 1867, mostrou sua intenção de resolver gradualmente a "questão servil";

5) a ação pessoal do Imperador e da Princesa Regente.

Quanto às duas primeiras categorias, "formavam círculos concêntricos, compostos como eram em grande parte dos mesmos elementos. É a elas que pertence o grosso do partido abolicionista ${ }_{2}$ os líderes do movimento" 63 .

$O$ depcimento $\epsilon$ o que se pode considerar de idôneo em matéria de campanha abolicionista. Nabuco se inclui no primeiro grupo, enquanto deputado do Partido Liberal, defensor de medidas jurídicas, fundador do jornal $O$ Abolicionista (1881) e autor de uma obra de combate densa e bela, $O$ Abolicionismo (1883). O seu testemunho merece algumas reflexóes que incidam na caracterização ideologica dos abolicionismos.

Pode-se começar pela sugestão de Nabuco formando uma categoria ampla que abrace os grupos concêntricos dos reformistas e dos militantes. $E$ fazer outro tanto com os demais. Deixando para o lugar oportuno o destaque das diferenças internas, teríamos dois perfis de antiescravistas:

Para os primeiros, o desafio social e ético que a sociedade brasileira teria

62 BOCAYUVA, Q. A crise da lavoura. Rio, Tip. Perseverança, 1868.

63 NABUCO, J. Minha formação, op. cit., p. 196. 
de enfrentar era o de redimir um passado de abjeção, fazer justiça aos negros, dar-lhes liberdade a curto prazo e integra-los em uma democracia moderna.

No horizonte, viam um regime escorado na indústria, no trabalho assalariado, na pequena e média propriedade, no ensino primário gratuito, no sufrágio universal. Joaquim Nabuco, Rui Barbosa, José do Patrocínio, Andre Rebouças, Luís Gama, Antônio Bento e seus seguidores concebiam a abolição como a medida mais urgente de um programa que se cumpriria com a reforma agrária, a democracia rural (a expressão é de Rebouças) e a entrada dos trabalhadores em um sistema de concorrência e oportunidade.

As raízes culturais dessa perspectiva mergulham fundo no discurso dos filantropos europeus da primeira metade do século XIX, lidos e citados entre nós desde os anos 50, e, mais diretamente, nos modelos econômicos ingleses e norte-americanos que constituíam o ideal do novo liberalismo ${ }^{64}$.

As razōes de teor progressista já se vinham articulando com nitidez no discurso que se formou depois da supressão do tráfico. Os marcos mais ostensivos são as obras de dois pontas-de-lança de nossa crítica social em um sentido já francamente liberal-capitalista: Tavares Bastos e Perdigão Malheiro.

Ambos começam a escrever na década de 60. As Cartas do Solitário saem em 1863. A primeira parte de $A$

Escravidão no Brasil, em 1866. E se quiséssemos remontar um pouco mais, até os anos 50, o nome expressivo seria o do pioneiro dos nossos empresários anglófilos, Irineu Evangelista de Sousa.
Tavares Bastos e Perdigão Malheiro, membros ativos do Instituto dos Advogados, forjaram as razōes jurídicas de um discurso que rompia os laços com o conformismo agroescravista. Os seus argumentos contra o latifúndio e em prol do trabalho livre irão colorir-se de matizes radicais e humanitários na campanha abolicionista dos anos 80 , mas a antinomia fundamental já fora exposta em seus ensaios: ou progresso, ou escravidão.

É compreensível que haja atuado uma diferença de ritmo social entre as duas geraçōes. Quando Rebouças, Nabuco e Patrocínio desfecharam a campanha pela abolição incondicional, o cativeiro se achava com os dias contados, e alguns políticos mais solertes do Oeste paulista já tinham desencadeado o processo da imigração européia. Mas o contexto em que se inseriam Tavares e Perdigão ainda dependia quase inteiramente do braço negro. Comparem-se as estimativas: 1.715 mil escravos em 1864 contra apenas $723.419 \mathrm{em} 1887$.

Em 1864, o liberalismo moderno, reformista, era um valor ideológico em busca de uma armadura logica, mas não ainda um grito de alarme por um problema que exigisse solução imediata; explica-se o gradualismo de algumas propostas daqueles dois pioneiros. A partir de 1880, a urgência saltava aos olhos da maioria: a campanha queria construir o dia de amanhã.

É importante ressaltar que não só de homens políticos se fez a militância. Um movimento intelectual forte, que retoma cientificamente os ideais das Luzes, estava em curso ao longo desses anos. Sílvio Romero resumiu-o com a expressão "um bando de idéias novas", fixando também em 1868 o seu ponto de partida ${ }^{65}$. Positivismo e

64 GRAHAM, Richard. A Grä-Bretanha e o intcio da Modernização no Brasil. São Paulo, Brasiliense, 1973. Para os detalhes dos projetos de reforma agrária, a leitura mais enriquecedora é a dos artigos de André Rebouças, escritos a partir de 1874 para o Jornal do Comércio, e depois reunidos nesta obra capital do novo liberalismo, $A$ Agricultura Nacional. Estudos econômicos. Propaganda abolicionista e democrática, Rio, Lamoureux, 1883.

65 ROMERO, Sîlvio. "Explicaçōes indispensáveis. (Prefácio) In: BARRETO, T. Vários escritos. Ed. do Estado de Sergipe, 1926. p. XXIII-XXIV. Euclides da Cunha fala em Era Nova para caracterizar o período pós-68 (À Margem da História). 
evolucionismo, Comte e Spencer, formam o eixo principal de referência. $O$ trabalho livre e um regime político mais representativo eram as metas a ser atingidas.

Os positivistas religiosos abraçaram logo as propostas mais radicais. Em 1884, Miguel Lemos abre o livro $O$ Positivismo e a Escravidão Moderna com uma dedicatória ao herói negro da rebeliāo de São Domingos:

"À Santa Memória/ do/ Primeiro dos Pretos/ Toussaint Louverture/ (1746-1803),/ Ditador do Haiti. Promotor e Mártir/ da liberdade/ de sua raça".

A obra é uma coleção de textos antiescravistas de Augusto Comte. Traz em apêndice os "Apontamentos para a solução do problema servil no Brasil", escrito datado de 22 de Shakespeare de 92 (30 de setembro de 1880) e assinado por Teixeira Mendes e outros ortodoxos. Nele já se repudia a imoralidade da criminosa herança colonial, acusa-se o delito nacional que foi a Guerra do Paraguai, argúi-se de ilegítimo o instituto da propriedade escrava; enfim, propōe-se que, libertado, o escravo se transforme em operário com número de horas previsto em lei, folga semanal e salário razoável. Teríamos aqui, em embrião, as medidas sociais preconizadas pelos jacobinos e, mais tarde, pelos tenentes discípulos do comteano Benjamin Constant?

Em manifesto de 21 de Dante de 95 (5 de agosto de 83), Miguel Lemos prega a abolição imediata, sem indenização aos senhores, e o aproveitamento dos libertos como assalariados. Bom ortodoxo, pede ao Imperador que aja como ditador, sem consultar o Parlamento, "que só serve para garantir a liberdade das mediocridades intrigantes", conforme já advertira o augusto mestre.

Há uma estreita faixa de intersecção ideológica que aproxima os novos

Ainda não foi explorado em toda a sua potencialidade $o$ veio reformista social do positivismo entre nós. liberais e alguns líderes repúblicos radicais como Silva Jardim, Luís Gama e Raul Pompéia. Para todos o divórcio das águas era a questão do trabalho livre. Guardavam, por isso, distância do núcleo paulista manobrado por fazendeiros ainda bastante conservadores na década de 70 e princípios da seguinte. "Os vossos barretes frígios são coadores de café" - frase de Pompéia lançada em rosto aos membros do Clube da Lavoura de Campinas - diz bem de um dissídio que se transformara em aberta oposição.

Ainda não foi explorado em toda a sua potencialidade o veio reformista social do positivismo entre nós. Ele fluirá, entre os oficiais jovens do Exército, dos jacobinos aos tenentes, em sua áspera luta antioligárquica de que a Coluna Prestes e a Revolução de $\mathbf{3 0}$ serão os momentos mais complexos. Em outra vertente, os esquemas políticos comteanos emprestariam moldes organizatórios a inquietudes sociais modernas que viriam a codificar-se no trabalhismo gaúcho de um Lindolfo Collor, a quem o positivista Getúlio Vargas nomeou primeiro Ministro do Trabalho em 1931, e de quem recebeu quase toda a nova legislação social. Legislação que, descontados os incisos corporativos, em boa hora cancelados pela última Constituinte, vem resistindo há mais de meio século e ainda hoje serve de espinha dorsal aos direitos trabalhistas brasileiros.

Cabe registrar uma diferença de modos de pensar a relação entre sociedade civil e Estado. $O$ positivismo ortodoxo (Miguel Lemos, Teixeira Mendes e, menos enfaticamente, Benjamin Constant) sustentava o projeto de um Estado centralizante, racionalizador $e$, no limite, tutelar. $O$ evolucionismo de tipo spenceriano (de um Sílvio Romero, por exemplo) pendia para o liberalismo clássico e acreditava na sabedoria da seleção natural que, mediante processos de concorrência, premiaria os mais capazes.

Coerentemente: os positivistas ortodoxos queriam um presidente forte, um cérebro ativo na chefia do Estado; os evolucionistas, ao contrário, farão o elogio do parlamentarismo burguês com suas reformas espontâneas, lentas $e$ graduais. Uns e outros, porem (e este é um signo da sua modernidade), 
propunham um modelo político que substituísse o do velho Império oligárquico e escravista.

Assim, voltando o nosso olhar para os anos cruciais de 1860-70, surpreenderemos um tom geral de inconformismo, uma ânsia de renovação, cujo alvo era desemperrar o regime monárquico: foi nesse clima que o novo liberalismo se gestou; e foi esse descontentamento que permitiu a filtragem ideológica diversificada das doutrinas européias.

A Guerra da Secessão americana dividiu, também entre nós, os dois campos: ao passo que um Varnhagen, padroeiro da historiografia tradicional, mostrava simpatia pelos fazendeiros do Sul, Tavares Bastos e Perdigāo Malheiro viam a luta do Norte e na figura de Lincoln exemplos de uma nova mentalidade que devia ser imitada. Neste, como em outros momentos de nossa história de idéias, as relaçōes entre os centros de poder e as suas periferias merecem receber um tratamento que não as reduza às afirmaçōes de tudo ou nada. Glosando uma hipotese de John Dewey sobre a formação da consciência pessoal, $\epsilon$ possível dizer que os grupos culturais e políticos das nações dependentes não apenas "sofrem" como também "escolhem" e trabalham as influências dos polos dominantes do sistema.

O reformismo liberal, que vai em crescendo de 1868 em diante, resulta de um embate interno cujas variáveis econômicas e sociais já foram inventariadas (extinção do tráfico, problemas de escassez da força de trabalho, aumento do mercado, urbanização, migração...). Ao mesmo tempo, cada um desses aspectos do sistema traz em si uma face internacional.

O confronto de nossas

particularidades com o movimento da História mundial, nessa fase de ascenso do imperialismo, ora aponta para variantes de um grande esquema de integração pós-colonial (a que esteve sujeita a América Latina inteira); ora dá relevo a certos aspectos diferenciados, raciais e culturais, que são tomados como próprios da nova formação nacional.
Este nacional, assim posto em evidência, pode ser abstraído - e potenciado - tanto pelos conservadores, que o adotam como bandeira tradicionalista (a patria del criollo), quanto, em registro oposto, pelos reformistas, que nele advertem um pólo catalisador dos grupos descontentes: foi o nacionalismo radical dos jacobinos do fim do século; foi o nacionalismo crítico dos tenentes de 1922-30.

O nacionalismo conservador exprimiu-se de modo orgânico nos anos de apogeu do Império escravista: está nas páginas eruditas da Revista do Instituto Histórico e Geográfico; permeia a rica messe documental da História Geral do Brasil do visconde de Porto Seguro; e é o cimento mítico do romance indianista e colonial de José de Alencar.

No outro extremo, o nacionalismo reformista ou radical quer o progresso em termos de elevação do Brasil ao plano da civilização ocidental.

Tavares Bastos prega uma política racional de migração, defende a abertura do Amazonas à cabotagem internacional, o que de fato ocorre em 1866 , ano em que também se instala o primeiro cabo transatlântíco entre a Europa e o Brasil. Perdigão Malheiro. que milita com Tavares Bastos no Instituto dos Advogados, faz minucioso levantamento das leis antiescravistas decretadas nos Estados Unidos, na Europa e nas colônias inglesas, francesas e holandesas das Indias ocidentais. $O$ Brasil se tornaria uma grande nação quando se erguesse ao nível dos padróes internacionais. A retórica de José Bonifácio, o moço, e de Castro Alves e Rui Barbosa, seus discípulos, irá na mesma direção, que já inclui lamentos e protestos contra a cumplicidade dos brasileiros no massacre dos negros. É o espírito de Vozes d'África e de $O$ Navio Negreiro. Algumas atitudes políticas de D. Pedro II parecem indicar que, embora hesitantemente, ele passou do pólo nacional-conservador para o pólo nacional-reformista, guiado pelo religioso respeito que the inspiravam as culturas inglesa e francesa. 
De resto, há coincidências expressivas que, muito provaveimente, são mais do que... meras coincidências. Um dos argumentos dos escravistas brasileiros era a comparaçāo que faziam entre a vida do nosso cativo e as agruras que então sofriam os proletários europeus acorrentados a uma jornada de trabalho que ia de dezesseis até dezoito horas diárias. Assim pensava Alencar. Viu-se, páginas atrás, como um negociante do Rio de Janeiro se referia aos "escravos" das fábricas inglesas para melhor escarmentar os philanthropists que combatiam a instituição. É instrutivo seguir o discurso paralelo nos debates que se travaram na França de Luís Filipe entre os adversários e os propugnadores da escravidão colonial nas Antilhas. Os deputados da Martinica e de Guadelupe encareciam o bom trato dado aos negros nas suas ilhas e deploravam a má sorte dos operários dos subúrbios parisienses.

Estes, porém, cerraram fileiras e enviaram um abaixo-assinado à Assembléia desmascarando as razões dos representantes coloniais. $\mathrm{O}$ documento vem citado no belo prefácio que Aimé Césaire fez à reedição dos textos do abolicionista Victor Schoelcher. Vale a pena transcrevê-lo na íntegra:
"Messieurs les Députés,

Les soussignés ouvriers de la capitale ont l'honneur, en vertu de l'article 45 de la Charte Constitutionnelle, de venir vous demander de bien vouloir abolir, dans cette session, l'esclavage. Cette lèpre, qui n'est plus de notre Époque, existe encore dans quelques possessions françaises. C'est pour obéir au grand principe de la fraternité humaine, que nous venons vous faire entendre notre voix en faveur de nos malheureux frères, les esclaves. Nous éprouvons aussi le besoin de protester hautement, au nom de la classe ouvrière, contre les souteneurs de l'esclavage, qui osent prétendre, eux qui agissent en connaissance de cause, que le sort des ouvriers français est plus déplorable que celui des esclaves. Aux termes du Code Noir, édition de 1685 , articles 22 et 25 , les possesseurs doivent nourrir et habiller leur bétail humain; il résuite des publications officielles faites par le ministère de la Marine et des Colonies, qu'ils se déchargent de ce soin, en concédant le samedi de chaque semaine aux esclaves. Ceux de la Guyane française n'ont même qu'un samedi nègre par quinzaine, contrairement aux défenses de l'article $24 \mathrm{du}$ Code Noir et aux pénalités de l'article 26.

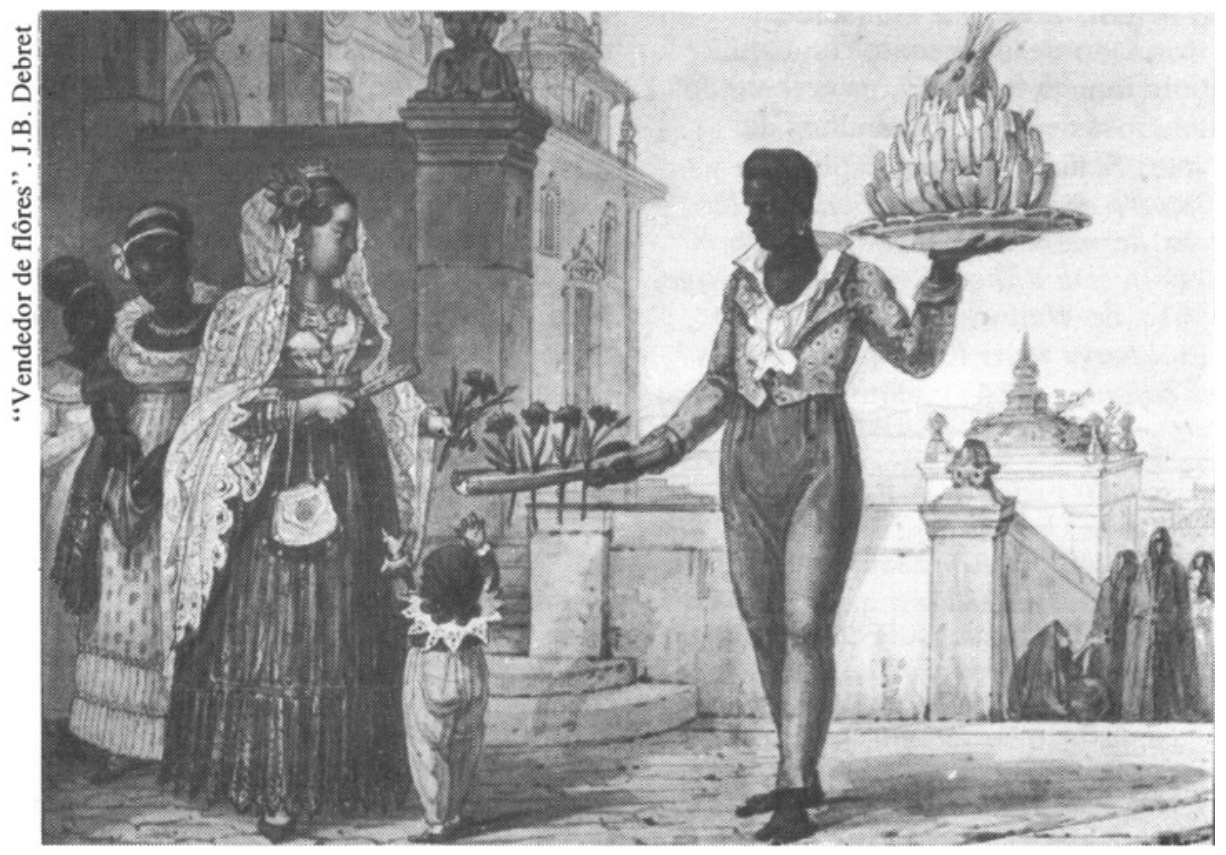


Quels que soient les vices de

l'organisation actuelle du travail en France, l'ouvrier est libre, sous un certain pount de vue, plus libre que les salariés défenseurs de la propriété pensante.

L'ouvrier s'appartient; nul n'a le droit de le fouetter, de le vendre, de le séparer violemment de sa femme, de ses enfants, de ses amis. Quand bien même les esclaves seraient nourris et habilles leurs possesseurs, on ne pourrait encore les estimer heureux, car comniè l'a si bien résumé $M$. le duc de Broglie, il faudrait autant dire que la condition de la bête est préférable à celle de l'homme, et que mieux vaut être une brute qu'une creature raisonnable. Fiers de la sainte et généreuse initiative que nous prenons, nous sommes sûrs que notre pétition aura de l'écho dans noble patrie, et nous avons confiance dans la justice des députés de France.

Paris, le 22 janvier 1844. Signe: Julien GALLE et 1505 signatures"66.

Comenta Aimé Césaire: "Nesse dia de 22 de janeiro de 1844 é selada a aliança de dois proietariados: $o$ proletariado operário da Europa, o proletariado servil das colônias".

Perdigão Malheiro, em A Escravidão no Brasil, revela-se altamente informado dessa recente campanha abolicionista francesa, mencionando numerosas vezes os trabalhos de Victor Schoelcher (em especial a Histoire de l'esclavage pendant les deux dernières années, 1847), de A. Cochin (De l'abolition de l' esclavage, 1861), de Wallon (Histoire de l'esclavage dans l'antiquité et dans les colonies, 1847), além de relatórios oficiais editados pelas comissōes parlamentares nos anos que precederam a abolição total nas colônias. A obra de Perdigão sera, por seu turno, referência obrigatória para os argumentos abolicionistas de Joaquim Nabuco entre 70 e 80 . Há, portanto, uma coerência interna no projeto reformista brasileiro, que soube incorporar, na sua justa medida, informaçōes vindas de movimentos franceses e ingleses que de pouco o precederam. Essa ligação estreita com a Europa liberal não altera (antes, reforça) a solidez doutrinária da nova ideologia que se exprime no Parlamento e na imprensa.

Do outro lado, a reaçāo do velho marquês de Olinda à questão formulada em abril de 67 pelo chefe de gabinete, Zacarias de Góis ("Convém abolir diretamente a escravidâo?'), define o ethos agromercantil que ainda não morrera. Respondeu Araújo Lima:

"Os publicistas e homens de Estado da Europa não concebem a situação dos países que têm escravidão. Para cá nāo servem suas idéias" 67 .

Para o ultraconservador Marquês a idéia da abolição gradual ainda soava, em 1867 (e apesar do apoio que lhe davam Pedro II e o presidente do Conselho), um eco de ideologias exóticas. No entanto, o processo já se fazia irreversível, "uma questāo de oportunidade e de forma", como o governo respondera à comissão de intelectuais franceses que lhe pedira a extinção do trabalho servil. Os debates parlamentares em 1871 revelariam que o novo liberalismo não avançaria sem dobrar tenazes resistências.68

66 SCHOELCHER, V. Esclavage et colonisation. Prefácio de Aimé Césaire. Paris, Presses Universitaires de France, 1948. p. 11.

67 NABUCO, J. Um Estadista ... op. cit., p. 613.

68 O tipo de mentalidade que Machado de Assis ironiza - e auto-ironiza enquanto narrador - $\epsilon$ o de parte da classe dominante que, ainda nos últimos anos do regime imperial, sustentou in abstracto a norma liberal moderna, ao mesmo tempo que racionaliza o uso do trabalho escravo, seu maior suporte econômico e político. Nesse contexto, o liberalismo clássico alardeado $\epsilon$, visto de fora, um despropósito, mas nem por isso deixa de ter conseqüências para o cotidiano da burguesia nacional. Esta $\epsilon$, em síntese, : a hipótese que Roberto Schwarz propôs e testou com felicidade em seu estado sobre Machado de Assis, Ao vencedor as batatas (S. Paulo, Duas Cidades, 1977). 
Convém agora voltar os olhos para a participação tardia, mas eficaz, dos que detinham os cordéis mais fortes da economia nacional: os fazendeiros do Centro-Sul.

À diferença das posiçōes de Tavares Bastos, Nabuco, Rebouças, Rui Barbosa, Luís Gama, Patrocínio e Antônio Bento, a consciência social dos cafeicultores e de seus porta-vozes no Parlamento se constituiu lentamente e sempre colada a seus planos econômicos de curto ou médio prazo. Se o objetivo dos primeiros era emancipar o escravo o quanto antes, a meta dos últimos era, e foi coerentemente, passar do trabalho escravo para o livre em tempo hábil e sem maiores prejuízos. Se, a uma certa altura (1886-88), os esforços de todos se cruzaram, provocando a Lei Áurea, o sentido imanente das açōes dos primeiros nunca se identificou com o das açōes dos segundos.

Os abolicionistas queriam libertar o negro; os cafeicultores precisavam substituir o negro. Daí, a diferença de ritmo e de acento. Os abolicionistas aceleravam o processo, porque pensavam em aliviar o sofrimento do escravo; os fazendeiros retardaram quanto puderam a ação do Estado, pois só cuidavam do quantum de mão-de-obra que ainda lhes seria dado arrancar aos derradeiros cativos antes de despachá-los para o vasto mundo da pura subsistência ou do lumpen.

As cautelas do Partido Republicano Paulista, que tanto indignaram Luís Gama, e a sua adesão de última hora só se compreendem à luz do contexto pragmático de onde saíram. Hoje, calados os louvores sem medida com que se exaltou a lucidez ou o espirito moderno dos fazendeiros do Oeste Novo, pode-se reconstituir com isenção os passos deveras prudentes dados pelos homens do café, desde a sua aberta recusa à Lei do Ventre Livre (os votos de Rodrigo Silva e Antônio Prado em 1871), até o seu ingresso no movimento já triunfante em 1887; então, o problema da força de trabalho já fora equacionado em termos de imigraçāo européia maciça subvencionada pelos governos imperial e provincial.

Os estudos de Conrad e Gorender, que ratificam, por sua vez, pontos de vista de Joaquim Nabuco e José Maria dos Santos, põem a nu a relutância dos republicanos paulistas, muito sensível nos anos 70, no que tocasse a medidas drásticas.

Em oposição aos liberais pós-68, como André Rebouças, que propunham o regime da pequena propriedade, a extinção imediata do trabalho compulsório e a modernização via indústria, os republicanos da grande lavoura centraram baterias no seu projeto de descentralização oligárquica. Cada província, de acordo com o espírito do Manifesto de 1873, deveria resolver, a seu modo e no tempo favorável, o problema da substituição do braço escravo. Nessa altura, o tráfico interprovincial ainda trazia levas consideráveis de negros do Nordeste para São Paulo, Rio e Minas Gerais.

"Em 1870, dizia-se na Assembléia Legislativa de São Paulo, que esta era a Província que menos deveria recear a diminuição de braços, pois aí estavam se concentrando todos os escravos do Norte do Império. Nessa ocasião, Paulo Egydio defendia a legitimidade do comércio de escravos, considerando-o "uma indústria muito legítima e consagrada entre nós'. Manifestava-se contra a restrição dessa liberdade pela sobrecarga de impostos: meia sisa, impostos imperiais e municipais, gravando as vendas" 69 .

A abolição que, para as províncias do Norte e Nordeste e para os profissionais urbanos, poderia vir sem maiores traumas, não interessava ainda aos fazendeiros de São Paulo que apenas esboçavam os seus projetos de migração. Um dado de fato: até 1880 o governo provincial de São Paulo nada gastou com a vinda de braços europeus. Para os bandeirantes

69 Atas da Assembléia Legislativa de Sâo Paulo de 1870 apud COSTA, Emília Viotti. Da Senzala à Colônia. São Paulo, Difel, 1966. p. 132. 
do cafe a ideologia conveniente parecia ainda ser a "beatitude physiocratica" que ja irritava os primeiros defensores sistemáticos da indústria nacional. Estes, citando exemplos franceses e yankees, lutavam por uma política protecionista que escorasse a nascente indústria. Mas em vão. O café mantinha a primazia absoluta. A Associaçāo Industrial clamava pela "proteção regeneradora das Leis do Estado, sem a qual elas irremediavelmente tombarāo no abismo em que já tem-se afundado muitas das suas irmãs"70.

Ao constituir-se, o Partido

Republicano Paulista receava confundir as suas águas com a mare montante do novo liberalismo do qual, porem, recebera alguns apoios significativos, rescaldos da crise política de 1868. Mas para pôr as coisas no seu devido lugar, advertia a Comissão do Partido aos 18 de janeiro de 1872:

“Aproveitando-me da oportunidade,
pedimos a vossa atenção e esforço no
intuito de neutralizar os meios com
que insidiosamente procura o
obscurantismo, consorciado com a má
fe, desconceituar os sectários da
democracia, apresentando-os como
propugnadores de doutrinas fatais
(sic) ao país. Entre as armas de que se
têm servido há uma que, manejada
com hábil pertinácia, pode chegar a
seu alvo. Referimo-nos ao boato,
adrede espalhado, de que o partido
republicano proclama e intenta pôr em
prática medidas violentas para a
realização da sua política e para a
abolição da escravidão (...) Cumpre
nāo esquecer que, se a democracia
brasileira consubstanciasse em suas
reformas práticas semelhantes
pensamentos, alienaria de si a maior
parte das adesões que tem, e as
simpatias que espera atrair. Sendo
certo que o partido republicano não

pode ser indiferente a uma questão altamente social, cuja soluçâo afeta todos os interesses, $\boldsymbol{\epsilon}$ mister entretanto ponderar que ele não tem e nem terá a responsabilidade de tal solução, pois que antes de ser governo, estará ela definida por um dos partidos monarquicos"71.

A partir desse momento separavam-se em São Paulo a propaganda republicana e a campanha abolicionista. No Congresso Republicano de 73 as posições se aclaram e precisam:

"Se o negócio for entregue a nossa deliberação", - diz o manifesto de 18 de abril - "n6s chegaremos a ele do seguinte modo:

19) Em respeito aos princípios da uniāo federativa cada província realizará a reforma de acordo com seus interesses particulares, mais ou menos lentamente, conforme a maior ou menor facilidade na substituição do trabalho escravo pelo trabalho livre;

29) Em respeito aos direitos adquiridos e para conciliar a propriedade de fato com o princípio da liberdade, a reforma se fará tendo por base a indenização ou resgate"72.

Luís Gama protestou com veemência, mas sua voz perdeu-se abafada por um silêncio constrangido. Essa seria a linha de neutralidade dos republicanos agrários, definida principalmente por Moraes Barros, Campos Salles, Francisco Glycerio, João Tibiriçá e Prudente de Moraes. O pragmatismo deste formulou-se de modo tático em sua intervenção parlamentar quando se discutia o Projeto Saraiva (em maio de 85), que resultou na Lei dos Sexagenários:

70 Em Biblioteca da Associação Industrial, "O Trabalho nacional e seus adversários", Rio, 1881, p. 13, apud CARONE, Edgard. O Pensamento industrial no Brasil (1880-1945). São Paulo, Difel, 1977. p. 151.

71 SANTOS, J.M. Os Republicanos paulistas e a abolição. São Paulo, Martins, 1942. p. 118-19.

72 lbid., p. 150. 
"Posso dizer, e creio que não serei contestado pelos representantes da minha província; na província de São Paulo, especialmente no Oeste que é a sua parte mais rica e próspera, a questão principal não $\epsilon$ a da liberdade do escravo. Os paulistas não fazem resistência, não fazem questão disto, do que eles fazem questão séria, e com toda razão, é da substituição e permanência do trabalho (apoiados de Antônio Prado, Rodrigo Silva e Martim Francisco), e desde que o governo cure seriamente de empregar os meios que facilitem a substituição do trabalho escravo, desde que facilite a aquisição de braços livres que garantam a permanência do trabalho, a conservação e desenvolvimento da sua lavoura, os paulistas estarão satisfeitos e não farão questão de abrir mão dos seus escravos, mesmo sem indenização, porque para eles a melhor, a verdadeira indenização está na facilidade de obter trabalhadores livres, está na substituição do trabalho" 73 .

O texto, em sua pesada redundância, fala por si. A adesão franca à campanha abolicionista da parte dos paulistas do Oeste estava, pois, condicionada a um subsídio oficial que fosse bastante copioso para a obtenção đōs braços livres. O subsídio veio em abundância: entre 87 e 88 chegariam aos nossos portos quase 150 mil imigrantes. Proclamada a República, sob o domínio do café, põe-se em marcha a grande imigração.

Resolvera-se o problema do trabalho assalariado. Mas não a questão do ex-escravo, a questão do negro. Para este, o liberalismo republicano nada tinha a oferecer. Foi o que logo perceberam os militantes do "novo liberalismo" que ainda se mantiveram fiéis à monarquia, Nabuco e

Rebouças, cuja correspondência traz contínuas acusacōes ao novo regime, "plutocrático"74.

Era também o pensamento de um mulato humilhado e ofendido pela República do Kaphet, Lima Barreto. Mas aqui já entramos em uma outra história: a história do negro e do mestiço depois da abolição. Quem a estudar deverá desfazer outro nó: não o que atou liberalismo e escravidão, mas o que ata liberalismo e preconceito.

73 Id. ibid., p. 225.

74 Nabuco a Rebouças, que se auto-exilara para a África no dia mesmo da proclamação da República: "Com que gente andamos metidos! Hoje estou convencido de que não havia uma parcela de amor do escravo, de desinteresse e de abnegação em três quartas partes dos que se diziam abolicionistas. Foi uma especulação mais! A prova é que fizeram esta República e depois dela só advogam a causa dos bolsistas, dos ladrỏes da finança, piorando infinitamente a condição dos pobres. É certo que os negros estão morrendo e pelo alcoolismo se degradando ainda mais do que quando escravos, porque são hoje livres, isto $e$, responsáveis, e antes eram puras máquinas, cuja sorte Deus tinha posto em outras mãos (se Deus consentiu na escravidão); mas onde estariam os propagandistas da nova cruzada? Desta vez nenhum seria sequer acreditado. (...) Estávamos metidos com financeiros, e não com puritanos, com fâmulos de banqueiros falidos, mercenários de agiotas etc.; tínhamos de tudo, menos sinceridade e amor pelo oprimido. A transformaçâo do abolicionismo em republicanismo bolsista é tão vergonhosa pelo menos como a do escravagismo" (Carta a Rebouças, Rio, $1^{\circ}$ de janeiro de 1893, transcrita em Joaquim Nabuco, Cartas a Amigos. São Paulo, Ipê, vol. I, p. 219). Mas já em 1884 Nabuco percebia a oposição entre o reformismo agrário dos novos liberais e a política do latifúndio: "Estamos no reinado do café, e é o café que maiores embaraços levanta ao resgate dos escravos" (Jornal do Comércio, 11/9/84).

Alfredo Bosi é professor-titular de Literatura Brasileira da FFLCH/USP e membro do Conselho Diretor do IEA. 